\title{
Volatility smiles when information is lagged in prices
}

Article

Accepted Version

Creative Commons: Attribution-Noncommercial-No Derivative Works 4.0

Marcato, G., Sebehela, T. and Campani, C. H. (2018) Volatility smiles when information is lagged in prices. North American Journal of Economics and Finance, 46. pp. 151-165. ISSN 1062-9408 doi: https://doi.org/10.1016/j.najef.2018.03.004 Available at https://centaur.reading.ac.uk/76287/

It is advisable to refer to the publisher's version if you intend to cite from the work. See Guidance on citing.

To link to this article DOI: http://dx.doi.org/10.1016/j.najef.2018.03.004

Publisher: Elsevier

All outputs in CentAUR are protected by Intellectual Property Rights law, including copyright law. Copyright and IPR is retained by the creators or other copyright holders. Terms and conditions for use of this material are defined in the End User Agreement.

\section{www.reading.ac.uk/centaur}

\section{CentAUR}

Central Archive at the University of Reading

Reading's research outputs online 


\title{
Volatility Smiles When Information is Lagged in Prices ${ }^{1}$
}

\author{
Gianluca Marcato ${ }^{2}$, Tumellano Sebehela ${ }^{3}$ and Carlos Heitor Campani ${ }^{4}$
}

Current Draft: March 2018

\begin{abstract}
This study explores volatility smiles when stock market information is lagged, specifically in the REIT industry. A usual requirement is that REITs can only disseminate information relating to their property valuations once per year; therefore, this leads to the lagging effect. Within the context of exchange options (i.e. mergers), it seems that no study has researched on this theme. This article uses the Black \& Scholes model to calculate implied volatilities and their corresponding implied options to illustrate arbitrage opportunities when exchange options emerge. The results illustrate that implied volatilities are different from non-implied volatilities. Further, arbitrage is still higher among REITs as opposed to other capital market instruments. Finally, just like other capital market instruments, REIT acquisitions generate alpha.
\end{abstract}

Keywords: Exchange option, lagged and volatility smile.

JEL: G12, G13

\footnotetext{
${ }^{1}$ We are grateful for valuable comments from John C. Cochrane, Simon Stevenson, Donald DePamphilis, Charles Ward, Chardin Wese Simen, Yingying Wu, Peter Carr and Zhiyao Chen. Matlab coding assistance from Giacomo Masato and Amos Lawless is highly appreciated. We're grateful to comments of two anonymous referees which led to the improvement of this article. All the remaining errors are own.

${ }^{2}$ HBS |University of Reading, Reading RG6 6UD, United Kingdom. E g.marcato@ henley.reading.ac.uk, T +44 (0)118 3788178.

3 [Corresponding author] CEM |WITS University, 1 Jan Smuts Avenue, P O Box 20, Wits 2050, Johannesburg, South Africa. E tumellano.sebehela@wits.ac.za, T +27(0)11 717-7668.

${ }^{4}$ COPPEAD-UFRJ, Cidade Universitária, 21941918 Rio de Janeiro, Brazil. E carlos.heitor@ coppead.ufrj.br, T +55 (21) 39389860.
} 


\section{Introduction}

This article explores implied volatilities of exchange option. Exchange option occurs when merger and acquisition (M\&A) deal is executed. The black-Scholes (1973) (from here B-S) model irrespective of the type of options, used to price transactions that are specifically cash-financed (see; Black and Scholes 1973, Barraclough et al. 2013 and Sebehela 2015). Furthermore, they stated that shareholders of a firm have an option in the form of common stocks that can either be callable or puttable. The B-S model is not industry-specific, hence its elegance in option pricing. In a no-basic arbitrage, investors would not be able to make extra profits other than profits that are due to them. However, given that stock markets are not always efficient, some investors do profit for stock market inefficiencies. One of the ways of finding out whether there is arbitrage within option pricing framework is by calculating implied volatilities. Implied volatilities illustrate ideal options when basic no-arbitrage principle holds.

Ideally, the volatility smiles should give rise to exchange option smile. Normally, academics and/or practitioners calculate smiles because stock prices diverted from the normal curves. In the context of an exchange option, share prices, $P$ of acquiring and target firms in relation to their fundamental prices, $P^{*}$ during acquisitions. One of the reasons why share and fundamental prices would diverge from each other within acquisitions framework would be when there is an "extra" value emanating from merger synergies. Normally, when the acquiring firm merges with target firm when stock markets are efficient it is expected that the option price represents the extra value for the target firm and "loss" for acquiring firm. More formally, if $t+1$ being the deal announcement date, then $P_{\text {Targ,t }}$ and $P_{A c q, t}$ represent the closing price of the target and acquiring company respectively at time $t$. If the option price at time $t$ is denoted by $O P_{t}$ then ceteris paribus, the theoretical price for the target and acquiring firms to be computed as follows:

$$
\begin{aligned}
& P_{\text {Targ }, t+1}^{*}=P_{\text {Targ }, t}+O P_{t} \\
& P_{A c q, t+1}^{*}=P_{A c q, t}-O P_{t}
\end{aligned}
$$

Since the announcement of the acquisition deal will make the shareholder of the acquiring firm suffer from a drop in price by $O P_{t}$, this amount should represent the fair price paid by the acquirer to access an extra value created by the merged entity. Given that the option price will always be at least equal to zero, it is expected that: 


$$
\begin{aligned}
& P_{\text {Targ }, t+1}^{*} \geq P_{\text {Targ }, t} \\
& P_{\text {Acq }, t+1}^{*} \leq P_{\text {Acq, } t}
\end{aligned}
$$

At the same time, it is known that the effective closing prices after the announcement will adjust to a level that may be different from the theoretical one:

$$
\begin{aligned}
& P_{\text {Targ }, t+1}^{*} \neq P_{\text {Targ }, t+1} \\
& P_{A c q, t+1}^{*} \neq P_{A c q, t+1}
\end{aligned}
$$

Past studies on diversion of share and fundamental prices cite different factors that cause diversion including options parameters, information asymmetry, momentum of share prices, assets valuations that underpin both share and options prices (see Glascock and Hung 2010). However, if acquisition leads to synergies due to arbitrage opportunities then equations (1) to (4) should not hold. One of the ways that arbitrage can be explained as follows, when the calculated option value is zero, then that deal should not be executed as it is invaluable and in the case where the option value is more than zero, the predator should not pay more the option amount; otherwise, there is an overpayment. Therefore, the difference between exercise and option price is arbitrage.

Academics and/or practitioners calculate implied volatilities, typically the equate observed option prices of the B-S theoretical prices, then solve for unknown volatility parameter, given information on option contracts and underlying asset prices. When such situation arises, intraday investors (i.e. trades) an advantage of such environment in several ways including using nonlinear and moments techniques (see Jones 2003). In this article, data is on the U.S. real estate investment trust (REIT) industry because; (i) the U.S. has the biggest REIT industry in the world, (ii) the U.S. is the first country in the world that passed REIT legislation in 1965, (iii) REITs are unique securities because they trade like shares while they are in fact units, (iv) unlike other capital market instruments, REITs are only allowed to disseminate information on their underlying assets once per financial year. The latter statement supports the notion that information captured by share prices of REITs is lagged. On the other hand, real estate appraisers can misprice property values, i.e. in the UK appraiser can misprice property values by $20 \%$. That is, information asymmetry due to lagging effect and mispricing is relatively high in REITs than any capital market instrument. Most studies that explored volatility smiles focus on 
currencies, commodities, fixed income securities and equities. To our knowledge, this is the first article that explores volatility smiles in the REIT industry.

The latter paragraph puts forward several questions including, are REIT volatility smiles differently to other capital market instruments; what about options calculated based on implied volatilities, especially implied exchange options. It seems that this is the first article that volatility smiles of exchange options in the REIT industry. Further, what are risk and return patterns in this case and finally do arbitrage opportunities lead to synergies? The contribution of this article is exactly answering those listed questions. One can infer from prior studies on volatility smiles that there are synergies (see Jones 2003 and Bayer et al. 2016). The risk is this article is measured with volatility. Although, volatility has is not a coherent risk measure such as expected short fall, but volatility is probably the best measure when one disaggregates risk pattern over a longer period (see Campbell et al. 2001). The results of this study illustrate that volatility smiles symbolizes the presence of arbitrage opportunities. Although the lagging effect is undesirable to most stock market participants, its presence in the REIT industry is beneficial, i.e. increase arbitrage which leads to higher option premium. The risk and return outcomes support what has been presented earlier, i.e. REIT mergers have diversification benefits. Similarly, to other industries mergers, REIT mergers generate alpha.

The rest of the article is organized as follows: section two is on literature review, section three is on general pricing, section four is on empirical analysis and the last section concludes the article.

\section{Literature Review}

The literature review for this article is divided in two sections; (i) volatility smiles as the article is shaped around volatility smiles subject area, (ii) implied options as this article is pricing implied exchange options, and (iii) variance swaps, as they volatility products, normally priced in an ideal environment. On the other hand, the second option explores how implied options are different from non-implied options.

\subsection{Volatility Smiles}

Hobson and Rogers (1998) presents different models when the volatility is stochastic. They argue that traded options are inconsistent with a constant volatility assumption. In presenting models, 
Hobson and Rogers (1998) start with non-constant volatility (NCV) models. Central to NCV models is that their volatility is dependent on stochastic process. Some of the processes that they put forward include constant elasticity of variance (CEV) and exponential Brownian motion (eBM). In those models, Hobson and Rogers (1998) state that prior studies illustrate that implied volatilities vary with changes in strike prices. Then, they present GARCH models, especially GARCH(1;1) model. The elegance of GARCH models is that they allow arbitrary past conditional variances and residuals. To do away with the shortcomings of the two groups of models, they expressed 'instantaneous volatility in terms of weighted moments of the historic log-price'. The pricing of options in Hobson and Rogers (1998) was centered on European contingent claim. The results illustrate that implied volatility are convenient when pricing securities across different security payoffs. They argue that if the non-constant term has increasing implied volatility, then initial offset is nonzero, and the option is not at-the-money.as expected, when implied volatility is high, so are option prices.

Gonçalves and Guildolin (2006) illustrate volatility dynamism on the S\&P500 (SPX) index. At heart of their study, is how the implied volatility surface (IVS) over time to expiration. This is because implied volatilities vary systematically with the option price and time to expiration. Other than contributing to purely modelling volatility surface, Gonçalves and Guildolin (2006) went further and explored time-series dimension. The main question time variation in the IVS, are there any gains in that situation? To answer that question, Gonçalves and Guildolin (2006) adopted application of vector auto-regression (VAR) models as illustrated in Dumas et al. $1998^{5}$. Although, there was data was lagged in their study, it was not due to information being dispersed into the market once per financial year, a common phenomenon in the REIT industry. Case et al. 2012 stated the same phenomenon in the REIT industry.

The data used is from Chicago Board Options Exchange (CBOE) on the SPX index options (calls and puts) covering the period of January 3, 1992-June 28, 1996. Gonçalves and Guildolin (2006) state that SPX options are European-style and expire the third Friday of each calendar month. Some data was not taken into account due to (i) thinly traded options (i.e. arbitrary cutoff chosen at 100 contracts per day), (ii) options that violate basic no-arbitrage conditions, (iii) discard data with fewer than six trading days to maturity, (iv) absolute excess moneyness of $10 \%$ and (v) exclude options with lower than $\frac{\$ 3}{8}$ to mitigate against discreteness on the IVS structure. The results show that implied volatilities are heterogeneous over time to expiration. For fitting

\footnotetext{
${ }^{5}$ More on the VAR model see; Dumas B, Fleming J and Whaley R (1998). Implied Volatility Functions: Empirical Tests. Journal of
} Finance, 53(6), 2059-2106. 
the implied volatility surface, results exemplify that a close relationship between raw and implied volatilities. They went further and modelled dynamics of implied volatility surface, using VAR and ordinary least squares (OLSs). The results were consistent with prior results in the Gonçalves and Guildolin (2006). When estimating VAR models on cross-sectional OLS estimates, the results were close to the multivariate model as opposed to Dumas et al. 1998.

To strengthen their results, Gonçalves and Guildolin (2006) did a predictability test on the outsample data. Data used for this section is from January 1, 1992-December 31, 1992; January 1, 1992-December 31, 1993 and so on until January 1, 1992-December 31, 1995. The results show that still show that, the multivariate model performs better than Dumas et al. 1998. The difference was small in absolute terms. The prediction errors decrease as the time to expiration approaches maturity. More, they tested the economic analysis based on different trading strategies; (i) A: trading strategies and rate of return calculations, (ii) B: trading profits before transaction costs, and (iii) C: trading profits after transaction costs. Trading strategies A and B achieved highest mean percentage profits and Sharpe ratios. And transaction costs eroded trading profits. Finally, the robustness test supports the notion that results are robust.

\subsection{Implied Exchange Options}

Empirical studies estimated implied volatilities of exchange options can be traced far back as 1987, i.e. Bhagat et al. 1987. Sorwar and Sudarsanam (2010) explored option pricing within M\&A framework and it is "shaped" around Bhagat et al. 1987. This empirical study adopts similar option pricing principles to Bhagat et al. 1987, and Sorwar and Sudarsanma (2010) but it is different in the sense it explores M\&A synergies in the U.S. REIT industry.

One thing that comes out of Bhagat et al. 1987 is that option pricing on M\&A captures more parameters such as information asymmetry when compared with CAPM. Option pricing model used in Bhagat et al. 1987 is the B-S model because exchange options are cash financed. The exact specifications of the B-S model including parameters used in Bhagat et al. 1987 will be explained later in the methodology part. The sample of Bhagat et al. 1987 is made up of tender offers over the period of July 1962 to December 1980 and the (+150;-21) window is used to analyze M\&A deals. Besides actual calculated options values and synergies, options techniques according to Bhagat et al. 1987 predict on how stocks portfolios and their risks behave. After the acquiring firm has declared its intention to take over the target firm, the predator exercise its call to enter the M\&A deal while target firm exercise its put when it accepts the offer. Hackbarth and 
Morellec (2008) echoed similar sentiments on acquiring firm declaring its intention to take over the target firm. Results illustrated that implied options show synergies emanating from exchange options; in addition, risks and returns measures confirm what is illustrated by options.

Sorwar and Sudarsanam (2010) is shaped around Bhagat et al. 1987 except that some principles and/or parameters were improved from the earlier empirical study. Among parameters improved include acceptable of convergence limit of $\left(P-P_{S}-F P_{p}\right)^{2} \leq 0.01$ versus convergence limit of $\left(P-P_{S}-F P_{p}\right)^{2} \leq 0.0625$ in Bhagat et al. 1987, where $P$ is the offer price, $P_{S}$ is the underlying stock price and $F P_{p}$ is the factional put (i.e. put amount which is percentage of target firm common stocks that will be taken over by acquirer). That formula for calculating implied volatilities and options will be discussed in detail in general pricing section of this article. Other thing that improves Sorwar and Sudarsanam (2010) in relation to Bhagat et al. 1987 is that the former theoretically and empirically illustrated takeover value of target firms and bid premiums. In addition, Sorwar and Sudarsanam (2010) illustrated that some puts show wealth transfer to target firms especially in cases where shareholders of target firms were overcompensated. The process where some target firms are overcompensated while other undercompensated within option pricing framework illustrates dynamic pricing when there are multiple factors driving option values. Dynamism within M\&A based on option pricing can be traced back to early 2000s. Dynamism in this context means merging and/or comparing option pricing within pricing techniques from other disciplines (see Subramanian 2004).

\subsection{Implied Non-Exchange Options}

The crux of Subramanian (2004) was on developing an arbitrage free model within complete market to price options emanating from mergers. Although, Subramanian (2004) agrees that the B-S model is appropriate in pricing cash financed deals, but he questions its validity when there is continuous diffusion. In developing the arbitrage free model, Subramanian (2004) stated that stock prices movements can be illustrated by stochastic differential equation (SDE). Thereafter, he expanded his model to include jumps depending on deals and portion of common stock taken over from target firm by acquirer. The stochastic process was driven by more than one stock price and evolution of M\&A dates were captured. To validate his model, he derived an Ito formula of that model. Conceptually, the arbitrage free model and Ito Lemma confirm similar views, that stock prices movements are stochastic, and the processes respond differently to M\&A dates (i.e. announcement and completion). The results calculated under complete markets 
illustrate that arbitrage free model captures more about M\&A deal when stock prices are discontinuous and stock jumps are modelled accordingly.

The elegance of Barraclough et al. 2013 can be found in the fact other than basing their methodology on prior studies, Barraclough et al. 2013 expand option pricing on M\&As such that things like M\&As announcements are captured in the model, likelihood of competing acquirer emerging in bidding for a target firm and disentangled gains of bidders and preys. Barraclough et al. 2013 used option pricing to explore overpayments in M\&As and questioned if those overpayments are due to synergies or not. The interesting thing about Barraclough et al. 2013 is that it combines asset pricing and option pricing to illustrated synergies. That is, they used a similar "linear" regression that incorporates options (i.e. put and calls) and prices (i.e. acquirer and target) to illustrated cases of overpayments and to whom those synergies accrue to. Moreover, Barraclough et al. 2013 considered probabilities of failure and success of M\&As deals. In Barraclough et al. 2013, some M\&As deals were hostile and others friendly, and some deals were called off (i.e. both hostile and friendly deals). Irrespective of the type of M\&As deal, results of Barraclough et al. 2013 illustrate that there are synergies on average which justified premium payments made to target firms in M\&As. They went further and tested the likelihood using logistic model, and results of logistic model confirmed similar results to options analysis. Moreover, logistic model illustrated that effective premium and relative size are statistically significant in determining synergies in M\&As.

Grullon et al. 2012 explored the positive relation between stock returns of firms and their volatilities within the real options framework. The key factors that were used as parameters of illustrate extra value are volatility, return-volatility relationship, convexity, flexibility, asset pricing techniques such as ARs and Fama-French (1993) three factor model. One of the main points that they put forward was that market returns and market volatility are negatively related to each other, although options values are positively related to market volatilities. Among reasons cited as casual of negative relationship between market returns and volatility is the presence of leverage. However, prior empirical studies such as Graham (1996) illustrated that debt increase options values because of volatility increases with debt increases.

Hypotheses tested by Grullon et al. 2012 were first, is there any value in firms that have abundance of investment opportunities; second, what is the impact of new information on options values of firms; third, sensitivity of volatilities on changes in growth options and assets 
values over time; fourth, return-volatility relationship when there are plenty growth and strategic opportunities; finally, volatility-return in relation to asset pricing models' performance. Daily data used by Grullon et al. 2012 is from CRSP over the period of January 1964 to December 2008. Measures used to calculate investment opportunities are firm size, R\&D expenditures and sales growth. Measures of investment and financing spikes are from COMPUSTAT.

Results from Grullon et al. 2012 illustrate that first, when there are abundant investment opportunities and the firms pays attention to timing of investments; then options values increase; second, real options capture information better than CAPM but CAPM cannot be ruled out especially when there is weak return-volatility relationship; third, options values, growth options in their case are sensitive to volatility changes and proper mitigation of volatility changes increase options values; fourth, volatility-return relationship is stronger in industries that exhibit plenty of growth and strategic opportunities, i.e. high-tech, pharmaceutical and biotechnology industries. Finally, in the presence of real options, CAPM explains underlying assets returns but no equity returns as equity returns are captured by real options model. All articles that have explored implied options are not on the REIT industry; this study explores implied volatilities and/or options in the REIT industry. To our knowledge, this is the first article that illustrates implied options and/or volatilities in the REIT industry.

\subsection{Variance Swap}

Cont and Kokholm (2013) modelled volatility smiles on a range of derivatives products including SPX and CBOE volatility index, simply known as VIX. They argue that volatility index gained popularity because of hedging reasons. It can be inferred from Cont and Kokholm (2013) that one of the reasons for pricing volatility surface in the context of variance products is because one wants to price those products in a consistent manner. Although, multifactor stochastic volatility (MSV) models can deal with some of the problems of pricing in a consistent manner; however, MSV models are incapable on features of the data as the magnitude of the VIX option skewness. In their pricing, they explore variance swaps, forward variance swap rates and options on forward variance swaps. In modelling dynamics of variance swaps and the underlying index of the model, Cont and Kokholm (2013) focused on variance swap dynamics, dynamics of underlying asset, vanilla options, and parametric processes; (i) Gaussian jumps, and (ii) exponential distributed jumps. 
The data used in Cont and Kokholm (2013) is from August 20, 2008 on a range of VIX put and call options for five maturities. The data is from $\mathrm{CBOE}$ and options with bids of zero are removed. The results of Cont and Kokholm (2013) illustrate those model specifications are achievable with very low calibration error. Further, implied prices fall within almost all bid-ask spread. Double exponential jumps are slightly better when compared with the first interval, but performance is independent of the 'choice of the jump size distribution'. The two specifications had similar goodness of fit. In addition, sensitivity is not influenced by model type.

Bayer at al. 2016 priced volatility smiles under rough environment for realized variance products. Given that Bayer et al. 2016 based their sample on SPX, in this article, the environment is much "rougher" than in Bayer at al. 2016 because the analysis is on REITs and information in the REIT industry is characterised by lagging effect and real estate industry is broadly more asymmetry than equities market. They specifically focused on pricing a daily logarithmic realized variance. For the pricing environment, Bayer at al. 2016 proposed rough fractional stochastic volatility (RFSV) model. They argue that the orientation of volatility surface changes over time but not the overall volatility surface. At crux of their study is that uncertain integrated variance over time to expiration should generate different implied volatilities.

The pricing in Bayer at al. 2016 was shaped around the change of measure. This includes pricing under a $\mathbb{Q}$ measure. Models used in Black-Scholes and rough Bergomi (rBergomi). First, the simulated the rBergomi such that they construct joint variance for the Volterra process $\widetilde{W}$ and Brownian motion $Z$. They find that volatility surface of rBergomi is close to SPX volatility surface, although, simulation of rBergomi are slow. Then, they estimate the curve for variance swap based on two dates; (i) February 4, 2010 and (ii) August 14, 2013. Bayer et al. 2016 claim that jumps are required to smiles of short periods indeed. Given that windows used this article are just for a few months, one hopes that smiles will be well captured. The results illustrate that the study by Bayer et al. 2016 show accurate prediction of volatility surface for high-frequency price data. 


\section{General Pricing}

\subsection{Portfolio Behaviour During Tender Period}

In illustrating results of event studies, windows are chosen arbitrarily (see Bhagat et al. 1987, Sorwar and Sudarsanam 2010, and Kinateder et al. 2017). Bhagat et al. 1987, and Sorwar and Sudarsanam (2010) used (+150;-21) window. Sebehela (2015) illustrated that longer windows are ideal when illustrate risks and returns. This article defines interval as consisting of 300-days pretender period and 32-days post M\&A announcement, (+300;-32) window. The 300-days pretender period is suitable for illustrating various parameters when there is so much information asymmetry and the cut off 32-days post-merger, is because due to data limitations, the transaction with shortest post data runs up to 32 days. In the REIT industry, properties illiquid which partly contribute to semi-strong efficient market hypothesis. In terms of the intensity of information, most intensity is found on target firms (see Sorwar and Sudarsanam 2010). Normally, market and stock risks are high pre-M\&A announcement but decrease towards M\&A completion period while returns are initially lower but increase post-M\&A completion. As firms announce their intention to merge, new information spillover to the market participants and that leads to risks decreasing post-M\&A announcement when compared to pre-offer period. Moreover, Dann et al. 1991 stated that if there are diversification benefits, risks should continue to decrease until M\&A is completed. On the other hand, Sorwar and Sudarsanam (2010) stated that the decrease pattern of risks and increasing returns during M\&A expiration period illustrate merging synergies.

\subsection{Implied Volatilities and Options}

Bhagat et al. 1987, and Sorwar and Sudarsanam (2010) are a few studies that priced exchange options in equities markets. Therefore, in estimating implied volatilities, this article will draw estimation techniques from Bhagat et al. 1987, and Sorwar and Sudarsanam (2010). The maximum options payoff illustrates the amount that option pays when it is in-the-money position. As stated in the introduction section, the B-S model is used to price cash-financed transactions. The put option of the B-S model is presented as follows:

$$
p=X e^{-r \tau} N\left(-d_{2}\right)-S_{0}\left(-d_{1}\right)
$$

with:

$$
\begin{aligned}
& d_{1}=\frac{\ln \left(\frac{S_{0}}{K}\right)+\left(r+\frac{\sigma^{2}}{2}\right) \tau}{\sigma \sqrt{T}} \\
& d_{2}=d_{1}-\sigma \sqrt{\tau}
\end{aligned}
$$


where $p$ is the put option, $S_{0}$ is the spot price (i.e., target price), $X$ is the exercise price (i.e. the deal value per share which SNL Financial calculates as amount paid for target acquisition over shares used to calculate deal, those shares include ordinary shares and operating units outstanding) and the exercise price in every M\&A deal for the entire time to expiration, $r$ is the continuous risk-free interest rate, $\tau$ is tau and it remaining days to the end of offer period, $\sigma$ is the volatility of the stock, $d_{1}$ and $d_{2}$ are probabilities of being in-the-money, and $N\left(d_{1}\right)$ and $N\left(d_{2}\right)$ are univariate cumulative normal density functions with upper integral limits $d_{1}$ and $d_{2}$ respectively. The volatility of target firm is estimated based on its historical prices as historical volatilities are model free. In the B-S model, the iteration process is used to estimate underlying stock value, implied volatilities of stocks and option values. Like Bhagat et al. 1987 and Sorwar and Sudarsanam (2010), it is assumed that $P$ is observable price, $P_{s}$ is unobservable price and $F P_{p}$ is a fractional put. The faction of the exchange $F$ may be any number between zero and one, $(0<F \leq 1)$, and in this empirical study exchange $F$ is 1.00 for all cash-financed transactions. Bhagat et al. 1987 and Sorwar and Sudarsanam (2010) illustrated that the equation illustrating the formula made up of $P, P_{s}$ and $F P_{p}$ is:

$$
P=P_{s}+F P_{p}
$$

Just like Bhagat et al. 1987, and Sorwar and Sudarsanam (2010), it is assumed that in equation (9) the stock price of underlying asset and its volatility are unobservable. The standard deviation is assumed to be constant over the offer period, for starting unobserved price $P_{S}$ of each M\&A deal, we start with implied prices calculation on day 3 of offer period. The reason why the starting options calculations are on day +3 of offer period is because REIT share prices jumps are avoided although jumps in REITs are minimal. Sorwar and Sudarsanam (2010) started their calculations on day 2 of offer period; it seems that they did that in order to avoid effects of share prices jumps as they used non-real estate data for their analysis. Initial standard deviation is one estimated as from day +1 . To solve for the price of underlying stock and/or to calculate implied volatilities, eq. (7) is re-stated as:

$$
P_{s}=P-F P_{p}
$$

For convergence the following equation should hold: 


$$
\left(P-P_{S}-F P_{p}\right)^{2} \leq 0.03
$$

The square of equation (12) is minimised, adjusting $P_{S}$ and $\sigma$ subject to a suitable tolerance limit. For each M\&A deal, iteration process of this study allows that there should be at most hundred iterations and those iterations occur for every offer day until day maturity of each M\&A deal. In eq. (12), the fraction $F$ is 1 while in Bhagat et al. 1987, and Sorwar and Sudarsanam (2010) $F$ ranged between 0 and 1 . The iteration process is subjected to "appropriate" tolerance limit. In this study, the tolerance limit is that estimated values should be within 3\% of their starting values. That is, eq. (12) should converge when the option premium is calculated to the accuracy of three pence. The tolerance limit of Bhagat et al. 1987 is 6.25\%, and Sorwar and Sudarsanam (2010) is $1 \%$ of their starting values. Bhagat et al. 1987 choose their tolerance limit based on number trades that occur on the New York Stock Exchange (NYSE), and in Sorwar and Sudarsanam (2010) the tolerance limit was based on the fact that out of their sample, 79 firms had a fraction of one.

This study wants to be closer to zero as minimising for zero is an ideal situation; however, given the fact that during 1994-2010 period, U.S. REITs declared at least 90\% of their profits as dividends, the probabilities of options were at least in-the-money positions, and to date there are no options written on U.S. REITs; therefore, there are significant anomalies which disturb equation (13) from converging to zero. Bhagat et al. 1987, and Sorwar and Sudarsanam (2010) stated that dividends lead to anomalies which made them to exclude some of the M\&A deals from their analysis. Bhagat et al. 1987 did highlight the problem of non-convergence due to options being in-the-money position but Sorwar and Sudarsanam (2010) did not explicitly stated problem of options being the in-the-money positions. In this empirical study, convergence of most M\&A deals occurs within the first iteration. In Bhagat et al. 1987, convergence occurred within the first three iterations, and Sorwar and Sudarsanam (2010) did not state number of iterations needed for their model to converge.

To avoid negative options and prices, a command is build that states stock prices should be positive (and options at least zero) as stock prices can never be less than zero. Similarly, implied option prices can never be less zero. In addition, option prices should be less than stock prices as this is consistent with reality. In Bhagat et al. 1987, and Sorwar and Sudarsanam (2010), implied stock prices, put options and volatilities are at least zero. In terms of testing whether implied standard deviations are acceptable, we adopted the same principles as Bhagat et al. 1987, and 
Sorwar and Sudarsanam (2010). Bhagat et al. 1987 went further to test whether their calculated implied results are sensitive to their starting values by repeating the procedure using one half and twice their original starting values of $P_{S}$ and $\sigma$.

They found that in all cases except one, convergence is the same for those different starting values. Sorwar and Sudarsanam (2010) did not state whether they tested as per latter statement. The entire process is continued until starting and ending values are within acceptable levels. Using estimating process, standard deviations are calculated such that starting value are at same level as $50 \%$ level of significance, then the procedure is ended and estimated $P_{p}, P_{s}$ and $\sigma$ are used. If the null hypothesis of chi-test is rejected at $50 \%$ level of significance, the entire procedure is re-starting all over again using the starting values of $\sigma$, the estimated $\sigma$ is from the derived series. The process is continued such that for chi-test starting and ending values of $\sigma$ are not rejected at significance level of 50\%. Similar assumptions are made by Bhagat et al. 1987 and Sorwar and Sudarsanam (2010).

\subsection{Measurements}

This section explores reasons for matching the sample and reasons on how and why ARs are used. The markets used in this empirical study are SPX and S\&P600 small-cap. The rationale of using SPX is that it includes constituents from all or major U.S. sectors of the economy including REITs; moreover, SPX has been existence since 1975. Given that some of the merging firms are non-real estate firms; therefore, SPX offer a fair representation of the market of analysing merging firms including REITs. On the other hand, REITs are largely small-cap to mid-cap stocks in terms of size; therefore, SPX small-cap index illustrates a suitable market that encompasses REITs in terms of size. "The small capitalization index (SMALL) is not regularly employed in computing a firm's beta; however, it is included due to research showing that REIT stocks behave similarly to small capitalization stocks", Anderson et al. 2009. To illustrate abnormal performance of REITs in relation to the markets, CARs are used. CARs are mostly used in REIT events studies to illustrate whether accumulation or distribution due to occurrence of certain events. In calculating CARs, first, ARs which are difference between actual and expected returns are calculated. ARs are calculated on securities and markets. To get CARs, ARs of a security and a market are subtracted from each other over a given period.

\subsection{Data}

The sample is made up of 106 completed public-to-public U.S. M\&A deals from SNL Financial. Cash finance deals make $38.68 \%$ (i.e. 41 deals); stocks financed make $47.17 \%$ (i.e. 50 deals) and 
stocks and cash deals make $14.15 \%$ (15 deals) of the sample. The 41 deals are within sectors and they specialise in multi-family, office, self-storage, industrial, shopping centres, diversified, health care and hotels. Only cash financed deals are analysed. Some of the cash financed deals were left out for poor data quality reasons. From the final sample of $41 \mathrm{M} \& \mathrm{~A}$ deals, 2 deals were taken off because target firms had prices less than 32 days post M\&A announcement although their time to expirations are more than 32 days post M\&A announcement. Then, on the remaining 39 M\&A deals, we calculated implied options for only $21 \mathrm{M} \& \mathrm{~A}$ deals as there is convergence problem on other M\&A deals. In certain cases, some deals from the final sample, the acquiring firm merged with more than one target firm during the period of 1996 to 2009; therefore, all different transactions per one acquirer and different target firms will be analysed. Acquisitions rates in all cash-financed deals are 100\% of target firms' outstanding shares. In terms of funding size of the deal, deals are worth at least $\$ 52.58$ million. Table 1 exemplifies cash deals sizes over M\&A period.

\section{[ INSERT TABLE 1 HERE]}

Most of REIT transactions fall within the small-caps and mid-caps categories ${ }^{6}$. The last subprime crisis occurred in 2008/2009; however, based GARCH (1;1), during periods of 1996-2009 and 2008-2009, the U.S. REIT industry was in the bull market phase as spot volatilities converge to their long-term average volatilities from the top ${ }^{7}$. For each deal, SNL Financial lists only the M\&A announcement and closing dates; therefore, it is assumed that all options are of European nature. The announcement date is decided in two ways, SNL Financial either takes the earliest event date as the announcement date or where there is letter of intent (LOI) dated prior to the definitive agreement date, SNL Financial registers the LOI date as the announcement date. The closure date is estimated by SNL Financial based on interviews with respective companies and should the actual date be different to one listed earlier on based on interviews, SNL Financial changes the date accordingly after deal completion. Therefore, only the modified date is observed.

\footnotetext{
${ }^{6}$ Mueller GR (1998). REIT Size and Earnings Growth: Is Bigger Better, or a New Challenge? Journal of Real Estate Portfolio Management, 4(2), 149-157.

${ }^{7}$ For further proof that the U.S. was in bull markets conditions, see; Sebehela T (2012). Exchange Options Hedging, IUP Journal of Financial Risk Management, IX(1), 55-63.
} 


\section{Main Results}

The results are presented as follows; (i) implied options and prices, (ii) risks and (iii) (excess) returns. This is to make the presentation as elegantly as possible. To strengthen the results, this study calculates chi-test for options and z-test on risks and (excess) for (0;-32) window. The reason why this study uses a chi-test is because options are truncated and non-linear in distribution.

\subsection{Implied Options and Prices}

Table 2 illustrates implied options and prices when target firms were taken over by acquiring firms.

\section{[ INSERT TABLE 2 HERE]}

The initial implied put options range from 0.00 to $\$ 43.97$ and in Bhagat et al. 1987 they ranged between $\$ 0.01$ and $\$ 9.77$. Sorwar and Sudarsanam (2010) did not show the range of implied put options. The zero options values might have been executed for strategic reasons, possibly future synergies. The initial put value over pre-offer price is $\$ 0.37$ on average and statistically insignificant, and for Bhagat et al. $\$ 6.25$, its significance is not indicated. Similarly, Yilmaz and Tanyeri (2016), Kinateder et al. 2017 and Yaghoubi et al. 2016a and 2016b found that merger generates value for shareholders. While Yilmaz and Tanyeri (2016), and Kinateder et al. 2017 illustrate most of benefits accrue to target shareholders, Yaghoubi et al. 2016a and 2016b show that mergers have a wavy pattern, i.e. benefits depend on the industry type and economic activity among other parameters. On the M\&A premium, this study finds that on average, target firms are paid M\&A premium, $\$ 5.05$ and statistically insignificant. M\&A premiums for Sorwar and Sudarsanam (2010) are $£^{0.26}$ and $£^{0.28}$ for entire and continuous samples respectively and both M\&A premiums are statistically significant. And for Bhagat et al. 1987 it is $\$ 2.71$, its significance is not indicated.

The apparent premium (i.e. offer price over underlying stock price after offer is made) is $\$ 13.71$. That is, on average target REIT firms get $\$ 13.71$ apparent premium from acquirers. The apparent premiums in Sorwar and Sudarsanam (2010) are $f^{0.34}$ and $f^{0.37}$ for entire and continuous samples respectively and they are both statistically insignificant. In Bhagat et al. 1987 apparent premium is $\$ 1.1114$ and the significance level is not indicated. Yilmaz and Tanyeri (2016) found 
that more (less) premium goes to target (acquiring) shareholders. While Yaghoubi et al. 2016a found premium is caused by either valuation error or hubris. Valuation error is applicable to the study as real estate appraisers are all to some level to misprice properties. Hubris is most likely not to apply as REIT mergers are friendly in nature (see Womack 2012). Yaghoubi et al. 2016b show that managers whose compensation is equity based, pay less premium. Yilmaz and Tanyeri (2016), Kinateder et al. 2017 and Yaghoubi et al. 2016a and 2016b argue that mergers are characterized by synergies. For this study, the average exercise price for $21 \mathrm{M} \& \mathrm{~A}$ deals is $\$ 20.54$ and synergies are $\$ 15.51$. Synergies as a proportion of exercise price are $30 \%$. The reason why synergies seem a bit "high" is because when a put option is preceded by call option, and options have the same time to expiration and underlying asset, options tend to be additive. Trigeorgis (1993) echoed similar view. Furthermore, it implies that exercise regions of individual options do not overlap. Furthermore, Trigeorgis (1993) stated that the subsequent option increases the value of underlying asset for prior options substantially.

More, this study adopts convergences ${ }^{8}$, and $\operatorname{CONV}_{u-c}\left(\mathrm{CONV}_{c-0}\right)$ is $-0.14(-0.08)$ and they are statistically insignificant. The reason for non-convergence is possibly due to the risk premium in the REIT industry. Generally, prices converge when there is a strong efficient market hypothesis, which is not in the case of REITs. The $C O N V_{c-0}$ in Sorwar and Sudarsanam (2010) is 0.06 and statistically significant because they used mainly financial data. Overall, the model in this empirical study estimates 54\% (21 out of 39 M\&A deals) of implied put options. Bhagat et al. 1987, and Sorwar and Sudarsanam (2010) estimate 9.41\% (8 out of 85 ) and 24.53\% (28 out of 115) respectively. In addition, this empirical study explores what drives implied put options and the independent variables. The latter statement is tested based on the log-linear model. The independent variables are as follows; complete (dummy 1 for completed and 0 for withdrawn) and agreed (dummy 1 for agreed and 0 otherwise). Hostile offers variable is excluded as there are no such offers in this empirical study. Other independent variables are length (offer period in days), 1996-00 (dummy 1 for 1996-00 and 0 otherwise) and 2001-04 (dummy 1 for 2001-04 and 0 otherwise). 1990-1995 variable is excluded as M\&A deals start in 1996 in this empirical study. Sorwar and Sudarsanam (2010) had 1990-1995 variable. It is expected that implied put options are positive functions of length, 1996-00 (UPREIT was introduced in 1994) and 2001-04 (most REIT mergers started early 2000s, especially large ones). Sorwar and Sudarsanam (2010) echoed similar views on length and 1996-00 in relation to implied put options.

\footnotetext{
${ }^{8}$ Convergences from Sorwar and Sudarsanam (2010)
} 


\section{[ INSERT TABLE 3 HERE]}

Table 3 illustrates that implied put options are positively related to length, 1996-00 and 2001-04 as per prior expectations. A positive relation between implied put options and 1996-00 and 200104 is illustrated by Sorwar and Sudarsanam (2010). In addition, this positive relationship is consistent with option pricing theory. The statistical significance of 1996-00 and 2001-04 can be attributed to earlier reasons. The length is statistically significant only at the $15^{\text {th }}$ and $16^{\text {th }}$ day post-M\&A announcement. This might be two points where implied put options are maximised because every independent variable is statistically significant. The White tests illustrate that there is no heteroscedasticity in all models and there is no autocorrelation as Durban-Watson ranges acceptable range (i.e. 1.5 to 2.5). F-statistics show that there are structural breaks in all models. This is due to the fact that small size is indeed small (i.e. $21 \mathrm{M} \& \mathrm{~A}$ deals) and analysis is based on cross sectional data. On the other hand, the White test, Durban-Watson, F-stat, Akaike, Schwarz, Hannan-Quinn illustrates that results are robust. Thereafter, risks measures are explored.

\subsection{Risks}

In measuring risks, this article is focused on disaggregating risks patterns as opposed to finding the actual risk at that point in time. For the $(0 ;-32)$ window, the standard deviation for target firms is implied one while for the acquiring firm is the actual standard deviation. That is, standard deviations for target firms do not include synergies while acquirers' standard deviations include synergies. In addition, beta dynamics are explored. Table 4 illustrates the main risk measures (beta and standard deviation).

\section{[ INSERT TABLE 4 HERE]}

Panel A shows that risks were lower post-M\&A announcement than pre-M\&A announcement probably due to the presence of synergies. The low betas for SPX and SPX small-cap imply that REITs act more like defensive stocks. The latter statement is consistent with the view that REITs exhibit small-cap and mid-cap characteristics. Moreover, results exemplify that REIT returns are "limited" as their betas are less than one in absolute terms. That is, REITs offer diversification benefits because their betas are negative (i.e. betas move in opposite direction to the markets). Another reason why U.S. REITs are different is that they are mainly focused. Even though REITs can diversify geographically, the amount of debt taken by REITs limits the benefits that come with geographical diversification. Campbell et al. 2001 illustrated that the geographical 
diversification dummy is statistically insignificant and Anderson et al. 2009 stated that specialised REITs trade at a premium to diversified REITs.

On the other hand, one can see that betas and standard deviations of acquiring firms are less than that of target firms. This confirms that that most of the risks are inherent in target firms than acquiring ones. Therefore, the latter statement partly explains why shareholders of target firms are compensated more than acquirers in mergers. Another thing that causes shareholders of target firms to be "overcompensated" is that during M\&A, shareholders forego dividends payout until the merger is completed. Therefore, shareholders of target firms might want to recover the "lost" compensation in the future. Similar views hold on standard deviations. Decrease in uncertainty post-M\&A announcement also lowers standard deviations. It should be borne in mind that negative betas are problematic for Treynor ratios as dividing by negative number changes the final calculation. Anderson et al. 2009 echoed similar views. The pre-M\&A announcement skewness when the representative market is the SPX show that betas of acquiring firm are positively skewed while of target firms are negatively skewed. However, post-M\&A announcement betas of acquiring firms are negatively skewed while of target firms are positively skewed. The latter statement supports the notion that risks decreased as distribution curves moved into opposite directions. The reduction in risks might be due to synergies. When the representative market is the SPX small-cap, there are hardly in changes when one compares preand post-M\&A announcement. This is probably because the constituents of the SPX small-cap have similar traits to REITs.

On the betas dynamics, Panel B in Table 4 illustrates that betas changes pre- and post-M\&A announcement are statistically significant. Thus, pre- and post-M\&A announcement risks are different in the sense that they tend to be smaller post-M\&A announcement when compared with the pre-M\&A announcement. Just like Sorwar and Sudarsanam (2010), this empirical study explores how ACQSZ, ANNRET, MKTRET and RUNUP affect betas 1 and 2. The B/M is excluded because SNL Financial has only the latest ones. In addition, the acquisition rates of ordinary outstanding shares of target firms for cash-financed deals are 100\%. Therefore, PCACQ is perfectly collinear with other independent variables. Hence, PCACQ is excluded from this analysis. The results in Panel C of Table 4 show that the RUNUP is negative and statistically significant because the acquirer is risky. ANNRET is positive and statistically significant; this might be due to information asymmetry embedded in the REIT industry. RELRISK for beta 1 is positive and statistically significant. This might be due to the same reasons as in ANNRET 
because there is a positive relationship between returns and risks in most securities. DurbanWatson illustrates that there is no autocorrelation in betas 1 and 2, and the White tests show that there is no heteroscedasticity in betas 1 and 2. There are structural breaks in betas 1 and 2 because the data is cross sectional one.

\section{3 (Excess) Returns}

The $(0 ;-10)$ window is representative of the REIT industry CARs given that stock prices of REIT firms are stable when compared with other industries. At the same time, this article calculates CARs for $(+1 ;-1)$ is standard to illustrate CARs for that window. The expected returns are illustrated by CAPMs. Table 5 illustrates (excess) returns.

\section{[ INSERT TABLE 5 HERE]}

CAPMs illustrate that expected returns are higher post-M\&A announcement when compared with the ones of pre-M\&A announcement. In addition, expected returns are statistically significant. The increase in expected returns post-M\&A announcement probably symbolises the presence of synergies among other things. The CARs for $(+1 ;-1)$ are all statistically significant. This illustrates that during that window, REIT acquisitions generate returns for shareholders. CARs for (+1;-1) in Yilmaz and Tanyeri (2016), Kinateder et al. 2017 and Yaghoubi et al. 2016a and $2016 \mathrm{~b}$ are statistically significant. More, Yaghoubi et al. 2016a and 2016b show that the abnormal performance in mergers is statistically significant. The statistical significance of differences in means might be interpreted as illustrating that contributions of acquirers and target firms to the merged entity are different. The z-test illustrates that CARs of acquirers and target firms over the same period are indifferent. This might be interpreted as REIT acquisitions hardly generate alpha. To verify whether REIT acquisitions hardly generate alpha, common used alpha (i.e. Jensen, Sharpe, SIM and Treynor) ratios are calculated. Table 6 reports alphas of acquiring and target firms.

\section{[ INSERT TABLE 6 HERE]}

There is no specific distributional pattern coming out of the Sharpe ratios, but post-M\&A announcement Sharpe ratios are higher than pre-M\&A announcement. However, the Sharpe ratios are statistically insignificant. The small Sharpe ratios coefficients might be interpreted as abnormal returns being "minimal" if they exist. The Treynor ratios illustrate similar pattern as the 
Sharpe ratios and some the Treynor ratios should be read with caution because of the problem of negative betas. Given that REITs are highly institutionalised and focused products, the calibre of management has influence on REITs performance. Jensen ratios illustrate that there are no alphas in REIT M\&A. This might be due the fact that hostile mergers are uncommon in the REIT industry although M\&A benefits are unequally distributed. The SIM ratios illustrate that the excess returns (ERs) on stocks and markets are equal, which might be interpreted as no one is advantaged than other party in REIT mergers. The statistical significance of some alphas might due to some stocks jumps when mergers are announced.

\section{Conclusion}

First, this article calculates implied volatilities of exchange options. Thereafter, implied exchange options are calculated based on implied volatilities. The volatility smiles of implied exchange options illustrate that there are arbitrage opportunities which symbolise the presence of synergies. Partly, those synergies illustrate that the option premiums emanating from emergence of exchange options. Thirdly, implied option values are driven by numerous economic parameters. The economic parameters in Table 3 for the $16^{\text {th }}$ implied option is all statistically significant, this might be interpreted that implied options are maximised at the $16^{\text {th }}$ implied option equations. The latter point is future research. Forth, the risk and return patterns exemplify phenomenon consistent with synergies presence. Thus, risks decrease post M\&A while returns increase during the same period. Finally, just like other capital mergers, REIT mergers generate statistically significant alpha.

The implications of this study are as follows: traders can use volatility smiles strategies to exploit REIT mergers. The latter strategy is commonly used in risk arbitrage strategies. Secondly, REIT mergers benefit both target and acquiring shareholders although benefits are inequitably distributed. Thirdly, REIT options can be used for hedging by larger REIT firms, especially mortgage ones. Finally, although leverage gives REIT firms first-mover advantage, leverage does not necessarily add value given stringent conditions attached to debt funding. 


\section{References}

Anderson RI, Benefield JD and Zumpano LV (2009). Performance Differences in Property-Type Diversified Versus Specialized Real Estate Investment Trusts (REITs). Review of Financial Economics, 18 (2): 70-79.

Barraclough K, Robinson DT, Smith T and Whaley RE (2013). Using Option Prices to Infer Overpayments and Synergies in M\&A Transactions. Review of Financial Studies, 26 (3): 695722.

Bayer C, Friz P and Gatheral J (2016). Pricing Under Rough Volatility. Mathematical Finance, 16(6), 887-904.

Bhagat S, Brickley JA and Loewenstein U (1987). The Pricing Effects of Interfirm Cash Tender Offers. Journal of Finance, 42 (4): 965-986.

Black F and Scholes M (1973). The Pricing of Options and Corporate Liabilities. Journal of Political Economy, 81 (3): 637-654.

Campbell JY, Lettau M, Malkiel BG and Xu Y (2001). Have Individual Stocks Become More Volatile? An Empirical Exploration of Idiosyncratic Risk. Journal of Finance, 56(1), 1-43.

Case B, Yang Y and Yildirim Y (2012). Dynamic Correlations Among Asset Classes: REIT and Stock Returns. Journal of Real Estate Finance \& Economics, 44(3), 298-318.

Chi T and McGuire DJ (1996). Collaborative Ventures and Value of Learning: Integrating the Transaction Cost and Strategic Option Perspectives on the Choice of Market Entry Modes. Journal of International Business Studies, 27 (2): 285-307.

Cont R and Kokholm T. (2013). A Consistent Pricing Model for Index Option and Volatility Derivatives. Mathematical Finance, 23(2), 248-274.

Dann LY, Masulis RW and Mayers D (1991). Repurchase Tender Offers and Earnings Information. Journal of Accounting \& Economics, 14 (3): 217-251.

Glascock JL and Hung S-YK (2010). Volatilities and Momentum Returns in Real Estate Investment Trust. Journal Real Estate Finance \& Economics, 41 (2): 126-149.

Gonçalves S and Guildolin M (2006). Predictable Dynamics in the S\&P500 Index Options Implied Volatility Surface. Journal of Business, 79(3), 1591-1635.

Graham JR (1996). Debt and the Marginal Tax Rate. Journal of Financial Economics, 41 (1): 41-73. 
Grullon G, Lyandres E and Zhdanov A (2012). Real Options, Volatility, and Stock Returns. Journal of Finance, LVII (4): 1499-1537.

Hackbarth D and Morellec E (2008). Stock Returns in Mergers and Acquisitions. Journal of Finance, LXIII (3): 1213-1252.

Hobson DG and Rogers LCG (1998). Complete Models with Stochastic Volatility. Mathematical Finance, 8(1), 27-48.

Jones CS (2003). The Dynamics of Stochastic Volatility: Evidence from Underlying and Options Markets. Journal of Econometrics, 116 (1-2), 181-224.

Kinateder H, Fabich M, and Wagner N (2017). Domestic Merger and Acquisitions in BRICS Countries: Acquirers and Targets. Emerging Market Review, 32, 190-199.

Sebehela T (2015). Exchange Options in the REIT Industry. Ph.D. Thesis, University of Reading, UK.

Sorwar G and Sudarsanam S (2010). Determinants of Takeover Premium in Cash Offers: An Option Pricing Approach. Journal of Business Finance \& Accounting, 37 (5/6): 687-714.

Subramanian A (2004). Option Pricing on Stocks in Mergers and Acquisitions. Journal of Finance, LIX (2): 795-829.

Trigeorgis L (1993). The Nature of Option Interactions and the Valuation of Investments with Multiple Real Options. Journal of Quantitative \& Financial Analysis, 28 (1): 1-20.

Womack, KS (2012). Real Estate Mergers: Corporate Control and Shareholder Wealth. Journal of Real Estate Finance \& Economics, 44(4), 446-471.

Yaghoubi R, Yaghoubi M, Locke S and Gibb J (2016a). Mergers and acquisitions: A Review. Part 1, Studies in Economics and Finance, 33(1), 147-188.

Yaghoubi R, Yaghoubi M, Locke S and Gibb J (2016b). Mergers and acquisitions: A Review. Part 2, Studies in Economics and Finance, 33(1), 437-464.

Yilmaz IS and Tanyeri B (2016). Global Marger and Acquisition (M\&A) Activity: 1992-2011. Finance Research Letters, 17, 110-117. 
Table 1: Cash-Financed REIT Acquisitions Amounts during 1996-2009 Period

\begin{tabular}{|c|c|c|c|c|c|c|}
\hline \multirow{2}{*}{ Year } & \multicolumn{5}{|c|}{ \$ million } & \multirow{2}{*}{$\mathbf{N}$. } \\
\hline & Mean & Median & Min & $\operatorname{Max}$ & Std Dev & \\
\hline \multicolumn{7}{|c|}{ Panel A: Sample Distribution by Year } \\
\hline 1996 & 301.20 & 301.20 & 301.20 & 301.20 & 0.00 & 1 \\
\hline 1997 & 204.50 & 204.50 & 130.00 & 279.00 & 105.36 & 2 \\
\hline 1998 & 54.52 & 54.52 & 52.58 & 56.45 & 2.74 & 2 \\
\hline 1999 & 105.00 & 105.00 & 105.00 & 105.00 & 0.00 & 1 \\
\hline 2000 & 794.16 & 596.40 & 214.50 & $1,571.57$ & 699.82 & 3 \\
\hline 2001 & $1,411.10$ & $1,411.10$ & $1,411.10$ & $1,411.10$ & 0.00 & 1 \\
\hline 2002 & 525.30 & 525.30 & 525.30 & 525.30 & 0.00 & 1 \\
\hline 2003 & 492.00 & 382.30 & 102.60 & 991.10 & 454.29 & 3 \\
\hline 2004 & $4,628.10$ & $4,628.10$ & $2,039.90$ & $7,216.30$ & $3,660.27$ & 2 \\
\hline 2005 & $1,424.37$ & $1,292.91$ & 446.40 & $3,141.90$ & 917.12 & 6 \\
\hline 2006 & $3,375.38$ & $1,027.65$ & 224.70 & $24,472.70$ & $7,459.29$ & 10 \\
\hline 2007 & $4,866.75$ & $1,568.20$ & 435.00 & $20,546.10$ & $7,033.38$ & 7 \\
\hline 2008 & 239.62 & 239.62 & 239.62 & 239.62 & 0.00 & 1 \\
\hline 2009 & 75.30 & 75.30 & 75.30 & 75.30 & 0.00 & 1 \\
\hline Total Deals & & & & & & 41 \\
\hline \multicolumn{7}{|c|}{ Panel B: Sample Distribution by Period } \\
\hline 1996-1999 & 154.04 & 117.50 & 52.58 & 301.20 & 109.61 & 6 \\
\hline $2000-2009$ & $2,798.25$ & $1,140.45$ & 75.30 & $24,472.70$ & $5,398.14$ & 35 \\
\hline Total Deals & & & & & & 41 \\
\hline
\end{tabular}

Note: On average, Table 1 illustrates that most deals are small-caps to mid-caps based on definition from Mueller (1998). Moreover, most cash financed deals were executed in the 2000s, especially around mid-2000s (i.e. bull markets phase) because GARCH $(1 ; 1)$ illustrates that spot volatilities converge to their long-term average volatilities from the top. N.: is sample size. 
Table 2: Implied Put Options and Stock Prices

\begin{tabular}{|c|c|c|c|c|c|c|c|c|c|}
\hline Measure & Mean & Median & Min & Max & Std Dev & Kurtosis & Skewness & N.: & Chi-test \\
\hline Initial Put Value $(0 ;-1)(\$)$ & 4.96 & 0.99 & 0.00 & 43.97 & 11.03 & 9.35 & 3.04 & 21 & $\begin{array}{c}3.18^{*} \\
(0.0745)\end{array}$ \\
\hline Initial Put Value over Pre-Offer Price (\$) & 0.37 & 0.06 & 0.00 & 1.72 & 0.54 & 0.69 & 1.38 & 21 & $\begin{array}{c}0.26 \\
(0.6101)\end{array}$ \\
\hline Put Value/Pre-Offer Price (\%) & 0.11 & 0.06 & 0.00 & 0.30 & 0.11 & -1.05 & 0.70 & 21 & $\begin{array}{c}0.02 \\
(0.8875)\end{array}$ \\
\hline Put Value/Underlying Stock Value (\%) & 0.07 & 0.03 & 0.00 & 0.30 & 0.08 & 3.50 & 1.65 & 21 & $\begin{array}{c}0.02 \\
(0.8875)\end{array}$ \\
\hline Synergies $(\$)$ & 15.51 & 15.49 & 15.42 & 15.69 & 0.09 & -0.68 & 0.15 & 21 & $\begin{array}{c}0.00 \\
(1.0000)\end{array}$ \\
\hline Synergies/Exercise Price (\%) & 0.30 & 0.30 & 0.29 & 0.31 & 0.00 & -0.67 & -0.15 & 21 & $\begin{array}{c}0.00 \\
(1.000) \\
\end{array}$ \\
\hline Measure & Mean & Median & Min & Max & Std Dev & Kurt & Skew & N.: & Z-test \\
\hline $\begin{array}{l}\text { Offer Price minus underlying Stock Price } \\
\text { (after Offer is made) (\$) }\end{array}$ & 5.05 & 1.47 & 0.30 & 44.09 & 10.59 & 11.18 & 3.28 & 21 & $\begin{array}{c}0.77 \\
(0.2794)\end{array}$ \\
\hline $\begin{array}{l}\text { Offer Price over underlying stock Price } \\
\text { (after Offer is made) (\$) }\end{array}$ & 13.79 & 0.04 & -0.15 & 99.29 & 32.50 & 3.02 & 2.13 & 21 & $\begin{array}{c}0.97 \\
(0.3340)\end{array}$ \\
\hline Exercise Price (all deals) & 20.54 & 20.54 & 20.54 & 20.54 & 0.00 & -0.56 & 0.06 & 21 & $\begin{array}{l}0.00 * * * \\
(0.0000)\end{array}$ \\
\hline$C O N V_{u-c}$ & -0.14 & -0.13 & -0.43 & 0.03 & 0.09 & 5.17 & -1.68 & 21 & $\begin{array}{c}-0.19 \\
(0.1141)\end{array}$ \\
\hline$C O N V_{c-0}$ & -0.08 & -0.03 & -0.43 & 0.03 & 0.11 & 3.90 & -1.85 & 21 & $\begin{array}{c}-0.95 \\
(0.3289)\end{array}$ \\
\hline
\end{tabular}

Note: From the final sample of 41 M\&A deals, 2 deals were taken off because target firms had prices less than 32 days post M\&A announcement although their time to expirations are more than 32 days post M\&A announcement. Then, on the remaining 39 M\&A deals, we calculated implied options for only $21 \mathrm{M} \& \mathrm{~A}$ deals as there is convergence problem on other M\&A deals. Put value is the first put value after M\&A announcement. Mean, Median, Min, Max, Std Dev, Kurt and Skew are averages of samples; ***, ** and * denote significance at 1\%, 5\% and 10\% respectively. For the Chi-Test column, in each cell, the first number is Chi-stat and one in the bracket is the probability of the Chi-stat. Bhagat et al. 1987, and Sorwar and 
Sudarsanam (2010) calculated implied options for $(0 ;-21)$ window but we used $(0 ;-32)$ window as the shortest time to expiration for one M\&A deal is 32-days post M\&A announcement and we used the same window throughout the entire sample for consistence reasons when comparing different parameters. The reason why we use Chi-test for options related parameters is because options are truncated, and their payoffs are non-linear. We assume that exercise prices represent values of target firms as acquiring firm did valuations (i.e. exercise prices) on target before acquisitions. Sorwar and Sudarsanam (2010) did not state on how they determined underlying assets values. In deals were options amounts are zeros, those deals shouldn't have been executed and in cases were options are more than zero, predators shouldn't pay more than options amounts; otherwise, there is overpayment, possibly due to synergies. Hence, synergies are the differences of exercise and options prices. Chi and McGuire (1996) stated similar illustration for synergies. For the z-test, we test the difference between the mean and median because the median gives a picture about where are our most values concentrated while mean gives as averages of distribution. Sorwar and Sudarsanam (2010) followed the same principle on their t-test. Bhagat et al. 1987 did not do any test on their options. For price related parameters we use z-test because we calculated options for $(0 ;-32)$ window for each M\&A deal. Converges (CONVs) are adopted from Sorwar and Sudarsanam (2010), $\operatorname{CONV}_{u-c}=\left(\operatorname{CONV}_{u}-\operatorname{CONV}_{c}\right) / \mathrm{CONV}_{c}$ measures convergence of underlying target stock value, $V_{u}$, towards the closing target stock price $V_{c}$ on the final period of the offer period and $C O N V_{c-0}=$ $\left(\mathrm{CONV}_{c}-\mathrm{CONV}_{0}\right) / \mathrm{CONV}_{0}$ measures the convergence of closing stock price, $V_{c}$, to the offer price, $V_{0}$. N.: is sample size. 
Table 3: Estimated Put Value Regressions on Explanatory Variables (IO=Implied Option)

\begin{tabular}{|c|c|c|c|c|c|c|c|c|c|c|c|c|}
\hline Model & Const & Length & $1996-00$ & 2001-04 & $\operatorname{Adj} R^{2}$ & $\begin{array}{l}\text { White } \\
\text { Test }\end{array}$ & $\begin{array}{l}\text { Durbin- } \\
\text { Watson }\end{array}$ & F-Stat & Akaike & Schwarz & $\begin{array}{c}\text { Hannan- } \\
\text { Quinn }\end{array}$ & $\mathbf{N}$. \\
\hline IO 1 & $\begin{array}{l}-2.4538 \\
(0.2366)\end{array}$ & $\begin{array}{c}0.5305 \\
(0.2117)\end{array}$ & $\begin{array}{c}1.7355^{* * *} \\
(0.0005)\end{array}$ & $\begin{array}{c}0.6621 \\
(0.1042)\end{array}$ & $20.54 \%$ & $\begin{array}{c}2.2990 \\
(0.8903)\end{array}$ & 1.55 & $\begin{array}{l}2.7237^{*} \\
(0.0766)\end{array}$ & 3.11 & 3.30 & 3.15 & 21 \\
\hline IO 2 & $\begin{array}{l}-2.4506 \\
(0.2371)\end{array}$ & $\begin{array}{c}0.5299 \\
(0.2121)\end{array}$ & $\begin{array}{c}1.7354 * * * \\
(0.0005)\end{array}$ & $\begin{array}{c}0.6619 \\
(0.1042)\end{array}$ & $20.53 \%$ & $\begin{array}{c}2.2995 \\
(0.8902)\end{array}$ & 1.54 & $\begin{array}{l}2.7233^{*} \\
(0.0766)\end{array}$ & 3.11 & 3.30 & 3.14 & 21 \\
\hline IO 3 & $\begin{array}{l}-2.6424 \\
(0.1735)\end{array}$ & $\begin{array}{c}0.5669 \\
(0.1527)\end{array}$ & $\begin{array}{c}1.7411^{* * *} \\
(0.0005)\end{array}$ & $\begin{array}{l}0.6832 * \\
(0.0886)\end{array}$ & $20.88 \%$ & $\begin{array}{c}2.3996 \\
(0.8795)\end{array}$ & 1.57 & $\begin{array}{l}2.7569 * \\
(0.0743)\end{array}$ & 3.09 & 3.29 & 3.13 & 21 \\
\hline IO 4 & $\begin{array}{l}-2.5902 \\
(0.1830)\end{array}$ & $\begin{array}{c}0.5585 \\
(0.1613)\end{array}$ & $\begin{array}{c}1.7395^{* * *} \\
(0.0005)\end{array}$ & $\begin{array}{l}0.6895^{*} \\
(0.0852)\end{array}$ & $20.70 \%$ & $\begin{array}{c}2.4104 \\
(0.8784)\end{array}$ & 1.56 & $\begin{array}{l}2.7405^{*} \\
(0.0754)\end{array}$ & 3.08 & 3.28 & 3.13 & 21 \\
\hline IO 5 & $\begin{array}{l}-2.5879 \\
(0.1832)\end{array}$ & $\begin{array}{c}0.5581 \\
(0.1614)\end{array}$ & $\begin{array}{c}1.7393^{* * * *} \\
(0.0005)\end{array}$ & $\begin{array}{l}0.6895^{*} \\
(0.0851)\end{array}$ & $20.69 \%$ & $\begin{array}{c}2.4117 \\
(0.8782)\end{array}$ & 1.56 & $\begin{array}{l}2.7400^{*} \\
(0.0754)\end{array}$ & 3.08 & 3.28 & 3.13 & 21 \\
\hline IO 6 & $\begin{array}{l}-2.8909 \\
(0.1345)\end{array}$ & $\begin{array}{c}0.6201 \\
(0.1175)\end{array}$ & $\begin{array}{c}1.7483 * * * \\
(0.0005)\end{array}$ & $\begin{array}{l}0.7451 * \\
(0.0623)\end{array}$ & $20.48 \%$ & $\begin{array}{c}2.5241 \\
(0.8658)\end{array}$ & 1.58 & $\begin{array}{c}2.7173^{*} \\
(0.770)\end{array}$ & 3.08 & 3.27 & 3.12 & 21 \\
\hline IO 7 & $\begin{array}{l}-2.9284 \\
(0.1299)\end{array}$ & $\begin{array}{c}0.6278 \\
(0.1134)\end{array}$ & $\begin{array}{c}1.7493^{* * * *} \\
(0.0005)\end{array}$ & $\begin{array}{l}0.7524^{*} \\
(0.0613)\end{array}$ & $20.43 \%$ & $\begin{array}{c}2.5418 \\
(0.8638)\end{array}$ & 1.58 & $\begin{array}{l}2.7118^{*} \\
(0.0774)\end{array}$ & 3.08 & 3.27 & 3.12 & 21 \\
\hline IO 8 & $\begin{array}{l}-2.8685 \\
(0.1383)\end{array}$ & $\begin{array}{c}0.6157 \\
(0.1209)\end{array}$ & $\begin{array}{c}1.7474 * * * \\
(0.0005)\end{array}$ & $\begin{array}{l}0.7621 * \\
(0.0572)\end{array}$ & $20.26 \%$ & $\begin{array}{c}2.5570 \\
(0.8620)\end{array}$ & 1.57 & $\begin{array}{l}2.6940^{*} \\
(0.0787)\end{array}$ & 3.07 & 3.27 & 3.11 & 21 \\
\hline IO 9 & $\begin{array}{c}-2.867 \\
(0.1383)\end{array}$ & $\begin{array}{c}0.6154 \\
(0.1208)\end{array}$ & $\begin{array}{c}1.7473^{* * *} \\
(0.0005)\end{array}$ & $\begin{array}{l}0.7624 * \\
(0.0570)\end{array}$ & $20.25 \%$ & $\begin{array}{c}2.5588 \\
(0.8618)\end{array}$ & 1.57 & $\begin{array}{l}2.6933^{*} \\
(0.0847)\end{array}$ & 3.07 & 3.27 & 3.11 & 21 \\
\hline IO 10 & $\begin{array}{l}-2.8222 \\
(0.1479)\end{array}$ & $\begin{array}{c}0.6066 \\
(0.1295)\end{array}$ & $\begin{array}{c}1.7372^{* * *} \\
(0.0006)\end{array}$ & $\begin{array}{c}0.7623^{*} \\
(0.0568)\end{array}$ & $19.49 \%$ & $\begin{array}{c}2.6105 \\
(0.8559)\end{array}$ & 1.56 & $\begin{array}{l}2.6146^{*} \\
(0.0847)\end{array}$ & 3.07 & 3.29 & 3.13 & 21 \\
\hline
\end{tabular}




\begin{tabular}{|c|c|c|c|c|c|c|c|c|c|c|c|}
\hline IO 11 & $\begin{array}{l}-2.8206 \\
(0.1479)\end{array}$ & $\begin{array}{c}0.6060 \\
(0.1295)\end{array}$ & $\begin{array}{c}1.7370^{* * *} \\
(0.0006)\end{array}$ & $\begin{array}{l}0.7626^{*} \\
(0.0567)\end{array}$ & $19.48 \%$ & $\begin{array}{c}2.6125 \\
(0.8557)\end{array}$ & 1.56 & $\begin{array}{l}2.6136^{*} \\
(0.0848)\end{array}$ & 3.09 & 3.28 & 3.13 \\
\hline IO 12 & $\begin{array}{l}-2.9189 \\
(0.1264)\end{array}$ & $\begin{array}{c}0.6262 \\
(0.1100)\end{array}$ & $\begin{array}{c}1.7597 * * * \\
(0.0004)\end{array}$ & $\begin{array}{l}0.7642^{*} \\
(0.0566)\end{array}$ & $21.19 \%$ & $\begin{array}{c}2.5079 \\
(0.8676)\end{array}$ & 1.58 & $\begin{array}{l}2.7933^{*} \\
(0.0718)\end{array}$ & 3.05 & 3.25 & 3.10 \\
\hline IO 13 & $\begin{array}{l}-2.9713 \\
(0.1189)\end{array}$ & $\begin{array}{c}0.6369 \\
(0.1033)\end{array}$ & $\begin{array}{c}1.7613^{* * *} * \\
(0.0004)\end{array}$ & $\begin{array}{l}0.7559 * \\
(0.0600)\end{array}$ & $21.34 \%$ & $\begin{array}{c}2.4978 \\
(0.8687)\end{array}$ & 1.60 & $\begin{array}{l}2.8094 * \\
(0.0707)\end{array}$ & 3.06 & 3.25 & 3.10 \\
\hline IO 14 & $\begin{array}{l}-2.9703 \\
(0.1188)\end{array}$ & $\begin{array}{c}0.6368 \\
(0.1031)\end{array}$ & $\begin{array}{c}1.7612^{* * *} \\
(0.0004)\end{array}$ & $\begin{array}{c}0.7563^{*} \\
(0.0538)\end{array}$ & $21.35 \%$ & $\begin{array}{c}2.4993 \\
(0.8685)\end{array}$ & 1.60 & $\begin{array}{l}2.8092^{*} \\
(0.0708)\end{array}$ & 3.06 & 3.25 & 3.10 \\
\hline IO 15 & $\begin{array}{l}-3.0086 \\
(0.1147)\end{array}$ & $\begin{array}{l}0.6447 * \\
(0.0994)\end{array}$ & $\begin{array}{c}1.7623^{* * *} * \\
(0.0004)\end{array}$ & $\begin{array}{c}0.7637^{*} \\
(0.0579)\end{array}$ & $21.29 \%$ & $\begin{array}{c}2.5169 \\
(0.8666)\end{array}$ & 1.60 & $\begin{array}{l}2.8034^{*} \\
(0.0712)\end{array}$ & 3.06 & 3.26 & 3.10 \\
\hline IO 16 & $\begin{array}{l}-3.0078 \\
(0.1145)\end{array}$ & $\begin{array}{l}0.6446^{*} \\
(0.0993)\end{array}$ & $\begin{array}{c}1.7622^{* * *} \\
(0.0004)\end{array}$ & $\begin{array}{l}0.7639 * \\
(0.0577)\end{array}$ & $21.28 \%$ & $\begin{array}{c}2.5184 \\
(0.8664)\end{array}$ & 1.60 & $\begin{array}{l}2.8032^{*} \\
(0.0712)\end{array}$ & 3.06 & 3.25 & 3.10 \\
\hline IO 17 & $\begin{array}{l}-2.9290 \\
(0.1331)\end{array}$ & $\begin{array}{c}0.6286 \\
(0.1161)\end{array}$ & $\begin{array}{c}1.7597 * * * \\
(0.0004)\end{array}$ & $\begin{array}{l}0.7547^{*} \\
(0.0622)\end{array}$ & $21.14 \%$ & $\begin{array}{c}2.4822 \\
(0.8703)\end{array}$ & 1.59 & $\begin{array}{l}2.7870^{*} \\
(0.0723)\end{array}$ & 3.06 & 3.26 & 3.10 \\
\hline IO 18 & $\begin{array}{l}-2.9747 \\
(0.1267)\end{array}$ & $\begin{array}{c}0.6360 \\
(0.1103)\end{array}$ & $\begin{array}{c}1.7610^{* * *} \\
(0.0004)\end{array}$ & $\begin{array}{l}0.7474 * \\
(0.0625)\end{array}$ & $21.26 \%$ & $\begin{array}{c}2.4735 \\
(0.8714)\end{array}$ & 1.60 & $\begin{array}{l}2.7999 * \\
(0.0714)\end{array}$ & 3.07 & 3.27 & 3.11 \\
\hline IO 19 & $\begin{array}{l}-2.9738 \\
(0.1266)\end{array}$ & $\begin{array}{c}0.6379 \\
(0.1102)\end{array}$ & $\begin{array}{c}1.7609 * * * \\
(0.0004)\end{array}$ & $\begin{array}{l}0.7476 * \\
(0.0654)\end{array}$ & $21.25 \%$ & $\begin{array}{c}2.4767 \\
(0.8713)\end{array}$ & 1.61 & $\begin{array}{l}2.7997 * \\
(0.0714)\end{array}$ & 3.07 & 3.27 & 3.11 \\
\hline IO 20 & $\begin{array}{l}-2.9578 \\
(0.1295)\end{array}$ & $\begin{array}{c}0.6347 \\
(0.1099)\end{array}$ & $\begin{array}{c}1.7603^{* * *} * \\
(0.0004)\end{array}$ & $\begin{array}{l}0.7354^{*} \\
(0.0709)\end{array}$ & $21.31 \%$ & $\begin{array}{c}2.4756^{*} \\
(0.08713)\end{array}$ & 1.63 & $\begin{array}{l}2.8051 * \\
(0.0711)\end{array}$ & 3.07 & 3.27 & 3.11 \\
\hline IO 21 & $\begin{array}{l}-2.9569 \\
(0.1264)\end{array}$ & $\begin{array}{c}0.6346 \\
(0.1098)\end{array}$ & $\begin{array}{c}1.7602^{* * * *} \\
(0.0004)\end{array}$ & $\begin{array}{c}0.7355^{*} \\
(0.0708)\end{array}$ & $21.30 \%$ & $\begin{array}{l}2.8048^{*} \\
(0.0710)\end{array}$ & 1.64 & $\begin{array}{l}2.8048 * \\
(0.0710)\end{array}$ & 3.07 & 3.27 & 3.12 \\
\hline
\end{tabular}




\begin{tabular}{|c|c|c|c|c|c|c|c|c|c|c|c|c|}
\hline IO 22 & $\begin{array}{l}-2.8707 \\
(0.1413)\end{array}$ & $\begin{array}{c}0.6092 \\
(0.1281)\end{array}$ & $\begin{array}{c}1.7948^{* * *} \\
(0.0003)\end{array}$ & $\begin{array}{l}0.7727^{*} \\
(0.0609)\end{array}$ & $21.78 \%$ & $\begin{array}{c}2.4494^{*} \\
(0.08741)\end{array}$ & 1.64 & $\begin{array}{l}2.8565^{*} \\
(0.0678)\end{array}$ & 3.07 & 3.27 & 3.12 & 21 \\
\hline IO 23 & $\begin{array}{l}-2.8135 \\
(0.1513)\end{array}$ & $\begin{array}{c}0.5923 \\
(0.1419)\end{array}$ & $\begin{array}{c}1.8177 * * * \\
(0.0003)\end{array}$ & $\begin{array}{l}0.7973^{*} \\
(0.0559)\end{array}$ & $22.09 \%$ & $\begin{array}{c}2.4259 \\
(0.8767)\end{array}$ & 1.65 & $\begin{array}{l}2.8909^{*} \\
(0.0657)\end{array}$ & 3.08 & 3.27 & 3.11 & 21 \\
\hline IO 24 & $\begin{array}{l}-2.6401 \\
(0.1896)\end{array}$ & $\begin{array}{c}0.5608 \\
(0.1771)\end{array}$ & $\begin{array}{c}1.8119 * * * \\
(0.0003)\end{array}$ & $\begin{array}{c}0.8232^{* *} \\
(0.0469)\end{array}$ & $21.49 \%$ & $\begin{array}{c}2.4742 \\
(0.8713)\end{array}$ & 1.65 & $\begin{array}{l}2.8252^{*} \\
(0.0698)\end{array}$ & 3.07 & 3.26 & 3.11 & 21 \\
\hline IO 25 & $\begin{array}{l}-2.6713 \\
(0.1754)\end{array}$ & $\begin{array}{c}0.5692 \\
(0.1591)\end{array}$ & $\begin{array}{c}1.7859 * * * \\
(0.0004)\end{array}$ & $\begin{array}{l}0.7961 * \\
(0.0519)\end{array}$ & $21.10 \%$ & $\begin{array}{c}2.5032 \\
(0.8681)\end{array}$ & 1.65 & $\begin{array}{l}2.7831^{*} \\
(0.0725)\end{array}$ & 3.06 & 3.26 & 3.11 & 21 \\
\hline IO 26 & $\begin{array}{l}-2.5343 \\
(0.2058)\end{array}$ & $\begin{array}{c}0.5475 \\
(0.1823)\end{array}$ & $\begin{array}{c}1.7180 * * * \\
(0.0006)\end{array}$ & $\begin{array}{l}0.7563^{*} \\
(0.0630)\end{array}$ & $18.29 \%$ & $\begin{array}{c}2.7149 \\
(0.8437)\end{array}$ & 1.63 & $\begin{array}{l}2.4925^{*} \\
(0.0949)\end{array}$ & 3.10 & 3.30 & 3.15 & 21 \\
\hline IO 27 & $\begin{array}{l}-2.5505 \\
(.1980)\end{array}$ & $\begin{array}{c}0.5577 \\
(0.1698)\end{array}$ & $\begin{array}{c}1.6932 * * * \\
(0.0007)\end{array}$ & $\begin{array}{l}0.7101 * \\
(0.0783)\end{array}$ & $18.44 \%$ & $\begin{array}{c}2.6367 \\
(0.8529)\end{array}$ & 1.62 & $\begin{array}{l}2.5072^{*} \\
(0.0936)\end{array}$ & 3.09 & 3.29 & 3.14 & 21 \\
\hline IO 28 & $\begin{array}{l}-2.6098 \\
(0.1875)\end{array}$ & $\begin{array}{c}0.5699 \\
(0.6105)\end{array}$ & $\begin{array}{c}1.6945^{* * *} \\
(0.0007)\end{array}$ & $\begin{array}{l}0.7002^{*} \\
(0.0838)\end{array}$ & $18.57 \%$ & $\begin{array}{c}2.6241 \\
(0.88543)\end{array}$ & 1.63 & $\begin{array}{l}2.5201 * \\
(0.0925)\end{array}$ & 3.10 & 3.20 & 3.14 & 21 \\
\hline IO 29 & $\begin{array}{l}-2.6283 \\
(0.1844)\end{array}$ & $\begin{array}{c}0.5738 \\
(0.1577)\end{array}$ & $\begin{array}{c}1.6946 * * * \\
(0.0007)\end{array}$ & $\begin{array}{l}0.6968^{*} \\
(0.0856)\end{array}$ & $18.60 \%$ & $\begin{array}{c}2.6215 \\
(0.8546)\end{array}$ & 1.64 & $\begin{array}{l}2.5229 * \\
(0.0923)\end{array}$ & 3.11 & 3.30 & 3.15 & 21 \\
\hline IO 30 & $\begin{array}{l}-2.5304 \\
(0.2002)\end{array}$ & $\begin{array}{c}0.5540 \\
(0.1715)\end{array}$ & $\begin{array}{c}1.6911 * * * \\
(0.0007)\end{array}$ & $\begin{array}{l}0.6792 * \\
(0.0929)\end{array}$ & $18.71 \%$ & $\begin{array}{c}2.5795 \\
(0.8595)\end{array}$ & 1.63 & $\begin{array}{l}2.5341^{*} \\
(0.0913)\end{array}$ & 3.10 & 3.30 & 3.14 & 21 \\
\hline IO 31 & $\begin{array}{l}-2.5559 \\
(0.1920)\end{array}$ & $\begin{array}{c}0.5593 \\
(0.1640)\end{array}$ & $\begin{array}{c}1.6914^{* * *} \\
(0.0007)\end{array}$ & $\begin{array}{c}0.6599 \\
(0.1023)\end{array}$ & $19.04 \%$ & $\begin{array}{c}2.5436 \\
(0.8636)\end{array}$ & 1.63 & $\begin{array}{l}2.5679 * \\
(0.0836)\end{array}$ & 3.10 & 3.30 & 3.15 & 21 \\
\hline IO 32 & $\begin{array}{l}-2.5013 \\
(0.2018)\end{array}$ & $\begin{array}{c}0.5482 \\
(0.1725)\end{array}$ & $\begin{array}{c}1.6892^{* * * *} \\
(0.0007)\end{array}$ & $\begin{array}{c}0.6503 \\
(0.1073)\end{array}$ & $19.08 \%$ & $\begin{array}{c}2.5245 \\
(0.8657)\end{array}$ & 1.63 & $\begin{array}{l}2.5716^{*} \\
(0.0882)\end{array}$ & 3.11 & 3.31 & 3.15 & 21 \\
\hline
\end{tabular}


Note: A log-liner model is used, i.e. $\ln \left(Y_{t}\right)=A+\beta_{1} X_{1 t}+\beta_{2} X_{2 t}+\mu_{t}$ because the dependent variable; implied options (IOs) are non-linear in distribution, $A$ is a constant (i.e. y intercept), $\beta_{1}$ and $\beta_{2}$ are estimated parameters, and $X_{1 t}$ and $X_{2 t}$ are independent variables, $\mu_{t}$ is the mean and $Y_{t}$ is dependent variable. Regressions are named after implied options values and each implied options regression represent options during a certain time for the $(0 ;-32)$ window of $21 \mathrm{M} \& A$ deals. We used the same independent variables as Sorwar and Sudarsanam (2010); length is the offer period in days (the neutral $\log$ of days for the regression variable are taken), 1999-00 is period of dummy variable that equates to 1 for 1996-2000 and zero otherwise. For length Sorwar and Sudrasanam (2010) used offer period in years but in this case that definition made the length variable to have a contrary coefficient to OPT and expectations; hence, the length is "changed". The 2001-2004 is the dummy variable that equates to 1 for 2001-2004 and 0 otherwise. The first period, 1990-1995 is not part of these regressions as data starts from 1996. Complete (i.e. 1 for complete and 0 for withdrawn) and agreed (i.e. 1 for agreed and 0 for hostile) because the data is made up of all complete offers and we don't have hostile offers. N.: is sample size. 
Table 4: Risk Measures

Panel A: Risk Illustration

\begin{tabular}{|c|c|c|c|c|c|c|c|c|c|c|c|c|}
\hline Measure & Market & Window & Firm & Mean & Median & Min & Max & Std Dev & Kurtosis & Skewness & N. & z-test \\
\hline \multirow{8}{*}{ Beta } & \multirow{4}{*}{ S\&P 500} & \multirow{2}{*}{$(+150 ; 0)$} & Predator & -0.001 & -0.001 & -0.044 & 0.045 & 0.019 & 1.022 & 0.018 & 41 & $\begin{array}{c}0.14^{*} \\
(0.0557)\end{array}$ \\
\hline & & & Prey & -0.001 & -0.001 & -0.046 & 0.039 & 0.017 & 1.282 & -0.279 & 41 & $\begin{array}{c}-0.16^{*} \\
(0.0636)\end{array}$ \\
\hline & & \multirow{2}{*}{$(0 ;-32)$} & Predator & 0.000 & 0.000 & -0.023 & 0.021 & 0.012 & 0.312 & -0.060 & 41 & $\begin{array}{l}-0.07 * * \\
(0.0279)\end{array}$ \\
\hline & & & Prey & -0.006 & -0.003 & -0.048 & 0.029 & 0.017 & 3.139 & -0.229 & 41 & $\begin{array}{c}-0.50 \\
(0.1915)\end{array}$ \\
\hline & \multirow{4}{*}{$\begin{array}{l}\text { S\&P } 600 \\
\text { small-cap }\end{array}$} & \multirow{2}{*}{$(+150 ; 0)$} & Predator & 0.001 & -0.019 & -0.334 & 0.349 & 0.172 & -0.185 & 0.019 & 41 & $\begin{array}{c}0.37 \\
(0.1406)\end{array}$ \\
\hline & & & Prey & -0.219 & -0.026 & -1.145 & 0.402 & 0.461 & -0.411 & 0.103 & 41 & $\begin{array}{c}-1.34 \\
(0.4099)\end{array}$ \\
\hline & & \multirow{2}{*}{$(0 ;-32)$} & Predator & -0.013 & -0.019 & -0.204 & 0.158 & 0.105 & -0.161 & -0.101 & 41 & $\begin{array}{c}0.20^{*} \\
(0.0793)\end{array}$ \\
\hline & & & Prey & 0.016 & 0.018 & -0.208 & 0.244 & 0.123 & 0.943 & 0.129 & 41 & $\begin{array}{l}-0.04^{* *} \\
(0.0160)\end{array}$ \\
\hline \multirow{4}{*}{\multicolumn{2}{|c|}{ Std Dev }} & \multirow{2}{*}{$(+150 ; 0)$} & Predator & 0.015 & 0.015 & 0.014 & 0.016 & 0.000 & -0.178 & 0.154 & 41 & $\begin{array}{c}-0.30 \\
(0.1179)\end{array}$ \\
\hline & & & Prey & 0.043 & 0.043 & 0.042 & 0.045 & 0.001 & 13.036 & 1.370 & 41 & $\begin{array}{c}0.15^{*} \\
(0.0539)\end{array}$ \\
\hline & & \multirow{2}{*}{$(0 ;-32)$} & Predator & 0.015 & 0.015 & 0.015 & 0.016 & 0.000 & 0.092 & 0.043 & 41 & $\begin{array}{c}0.80 \\
(0.2881)\end{array}$ \\
\hline & & & Prey & 0.036 & 0.006 & 0.001 & 0.177 & 0.060 & 1.041 & 1.624 & 21 & $\begin{array}{c}1.14 \\
(0.3729)\end{array}$ \\
\hline
\end{tabular}




\section{Panel B: Beta Dynamics of Acquirers and Target Firms}

\begin{tabular}{|c|c|c|c|c|c|c|c|c|c|c|c|c|}
\hline Measure & Market & Window & Firm & Mean & Median & Min & Max & Std Dev & Kurtosis & Skewness & N. & z-test \\
\hline \multirow{9}{*}{ Beta } & \multirow{5}{*}{ S\&P 500} & $(+150 ; 0)$ & Predator & -0.001 & -0.001 & -0.044 & 0.045 & 0.019 & 1.022 & 0.018 & 41 & \multirow{2}{*}{$\begin{array}{c}0.01 * * * \\
(0.0004)\end{array}$} \\
\hline & & $(0 ;-32)$ & Predator & 0.000 & 0.000 & -0.023 & 0.021 & 0.012 & 0.312 & -0.060 & 41 & \\
\hline & & & & & & & & & & & & \\
\hline & & $(+150 ; 0)$ & Prey & -0.001 & -0.001 & -0.046 & 0.039 & 0.017 & 1.282 & -0.279 & 41 & \multirow{2}{*}{$\begin{array}{c}-0.06^{* *} \\
(0.0239\end{array}$} \\
\hline & & $(0 ;-32)$ & Prey & -0.006 & -0.003 & -0.048 & 0.029 & 0.017 & 3.139 & -0.229 & 41 & \\
\hline & \multirow{4}{*}{$\begin{array}{l}\text { S\&P } 600 \\
\text { small-cap }\end{array}$} & $(150 ; 0)$ & Predator & 0.001 & -0.019 & -0.338 & 0.349 & 0.172 & -0.185 & 0.019 & 41 & \multirow{2}{*}{$\begin{array}{c}-0.07 * * \\
(0.0279\end{array}$} \\
\hline & & $(0 ;-32)$ & Predator & -0.013 & -0.019 & -0.204 & 0.158 & 0.105 & -0.161 & -0.101 & 41 & \\
\hline & & $(150 ; 0)$ & Prey & -0.219 & -0.219 & -1.145 & 0.402 & 0.461 & -0.411 & 0.103 & 41 & \multirow{2}{*}{$\begin{array}{c}0.97 \\
(0.3340)\end{array}$} \\
\hline & & $(0 ;-32)$ & Prey & 0.016 & 0.018 & -0.208 & 0.244 & 0.123 & 0.943 & 0.129 & 41 & \\
\hline
\end{tabular}


Panel C: Acquirer Beta Dynamics Surrounding Acquisitions

\begin{tabular}{|c|c|c|c|c|c|c|c|c|c|c|c|c|c|c|c|}
\hline Model & Const & Acqsiz & Annret & Dealsiz & Mktret & Relrisk & Runup & $\begin{array}{c}\text { Adj } \\
\mathbf{R}^{2} \\
\end{array}$ & $\begin{array}{c}\text { White } \\
\text { Test }\end{array}$ & DW & F-Stat & AIC & SIC & HQ & N. \\
\hline Beta 1 & $\begin{array}{c}-2.64 \\
(0.417)\end{array}$ & $\begin{array}{c}0.33 \\
(0.456)\end{array}$ & $\begin{array}{c}2.91 * * * \\
(0.000)\end{array}$ & $\begin{array}{c}0.03 \\
(0.455)\end{array}$ & $\begin{array}{c}8.02 \\
(0.135)\end{array}$ & $\begin{array}{l}0.24 * * \\
(0.030)\end{array}$ & $\begin{array}{l}-0.97 * * * \\
(0.0000)\end{array}$ & 0.98 & $\begin{array}{l}35.46 \\
(0.13)\end{array}$ & 1.52 & $\begin{array}{c}421.47^{* * * *} \\
(0.000)\end{array}$ & 1.24 & 1.53 & 1.34 & 41 \\
\hline Beta 2 & $\begin{array}{c}-0.24 \\
(0.155)\end{array}$ & $\begin{array}{l}0.0043 \\
(0.827)\end{array}$ & $\begin{array}{c}2.93^{* * * *} \\
(0.000)\end{array}$ & $\begin{array}{c}0.02 \\
(0.561)\end{array}$ & $\begin{array}{c}-6.11 \\
(0.302)\end{array}$ & $\begin{array}{l}0.1933 \\
(0.110)\end{array}$ & $\begin{array}{c}-0.97 * * * \\
(0.0000)\end{array}$ & 0.98 & $\begin{array}{l}36.48 \\
(0.11)\end{array}$ & 1.56 & $\begin{array}{c}407.06^{* * *} \\
(0.000)\end{array}$ & 1.27 & 1.56 & 1.37 & 41 \\
\hline
\end{tabular}

Note: D-W is Durban-Watson statistics, beta and std dev are calculated for 2 markets; S\&P 500 and S\&P 600 small-cap respectively. For prey for (0;32) window, Std Dev is calculated based on implied stock prices. The reason why there are 21 firms for the prey for $(0 ;-32)$ window is because from the final sample of $41 \mathrm{M} \& A$ deals, 2 deals were taken off because target firms had prices less than 32 days post M\&A announcement although their time to expirations are more than 32 days post M\&A announcement. Then, on the remaining 39 M\&A deals, we calculated implied options for only 21 M\&A deals as there is convergence problem on other M\&A deals. On beta dynamics, principles of Sorwar and Sudarsanam (2010) are adopted, using a z-test (i.e. each window is 32 days post-M\&A announcement) we test for mean difference of firms (i.e. acquiring and target firms) pre-and postM\&A announcement. Just like Sorwar and Sudarsanam (2010), an ordinary least square (OLS) is used to determine what drives betas (change in acquirer's beta surrounding bid announcement, i.e. beta over day +1 to completion date less beta over day -31 relative to announcement date, day 0 ) then the betas are modelled against the independent variables; RUNUP (is the change in acquirer's beta in run to bid announcement, i.e. beta over - 31 to day -1 less the beta over - 252 days relative to day 0), ANNRET (is 3 day announcement return), DEALSIZ (is the deal-to-market value ratio, i.e. ratio of deal size to acquirer market capitalisation 4 weeks prior to announcement), MKTRET is one year return to market portfolio (S\&P 500 and S\&P 600 small-cap respectively) prior to bid announcement, PCACQ is percentage of shares acquired. RELRISK is ratio of acquirers to target's standard deviation of returns in a the1-year pre-offer period. ACQSIZ is market capitalisation of acquirer 2 weeks (4 weeks in case of Sorwar and Sudarsanam, 2010) prior to bid announcement. We didn't include B/M (book-to-market ratio with market cap taken 4 weeks prior to announcement and book value of equity from most recent accounting statement prior to that date) as SNL Financial does not provide B/M but total non-depreciable real estate value for book value (NDBV) and market capitalisation but only have latest values on NDBV and market caps. Acquirers acquired $100 \%$ targets; hence, PCACQ variable is perfectly collinear with other variables. For that reason, the PCACQ is left out. The equations, Beta 1 and Beta 2 are when markets are S\&P 500 and S\&P 600 small-cap respectively. N.: is sample size and for each window, $(+)$ indicates number of days before the event happens and (-) days after the event happened. 
Table 5: (Excess) Returns

\begin{tabular}{|c|c|c|c|c|c|c|c|c|c|c|c|c|}
\hline Measure & Market & Window & Firm & Mean & Median & Min & $\operatorname{Max}$ & Std Dev & Kurtosis & Skewness & $\mathbf{N}$. & z-test \\
\hline \multirow{8}{*}{ CAPM } & \multirow{4}{*}{ S\&P500 } & \multirow{2}{*}{$(+150 ; 0)$} & Predator & 0.032 & 0.032 & 0.029 & 0.034 & 0.001 & -0.133 & -0.032 & 41 & $\begin{array}{l}0.00^{* * *} \\
(0.0000)\end{array}$ \\
\hline & & & Prey & 0.041 & 0.041 & 0.037 & 0.045 & 0.002 & 0.076 & 0.117 & 41 & $\begin{array}{c}0.06^{* *} \\
(0.0239)\end{array}$ \\
\hline & & \multirow{2}{*}{$(0 ;-32)$} & Predator & 0.032 & 0.032 & 0.031 & 0.034 & 0.001 & 0.045 & -0.085 & 41 & $\begin{array}{c}0.07 * * \\
(0.0279)\end{array}$ \\
\hline & & & Prey & 0.043 & 0.043 & 0.040 & 0.046 & 0.001 & 1.300 & 0.190 & 41 & $\begin{array}{c}0.31 \\
(0.1217)\end{array}$ \\
\hline & \multirow{4}{*}{$\begin{array}{l}\text { S\&P600 } \\
\text { small-cap }\end{array}$} & \multirow{2}{*}{$(+150 ; 0)$} & Predator & 0.034 & 0.035 & 0.018 & 0.052 & 0.008 & 0.052 & 0.027 & 41 & $\begin{array}{c}-0.32 \\
(0.1255)\end{array}$ \\
\hline & & & Prey & 0.049 & 0.041 & 0.020 & 0.096 & 0.020 & 0.218 & -0.012 & 41 & $\begin{array}{c}1.31 \\
(0.4032)\end{array}$ \\
\hline & & \multirow{2}{*}{$(0 ;-32)$} & Predator & 0.035 & 0.035 & 0.025 & 0.045 & 0.005 & 0.198 & 0.014 & 41 & $\begin{array}{c}-0.25^{*} \\
(0.0987)\end{array}$ \\
\hline & & & Prey & 0.042 & 0.042 & 0.030 & 0.054 & 0.006 & 0.021 & -0.113 & 41 & $\begin{array}{c}0.03^{* *} \\
(0.0120)\end{array}$ \\
\hline \multirow{4}{*}{ CARs } & \multirow{2}{*}{ S\&P500 } & \multirow{2}{*}{$(0 ;-10)$} & Predator & -0.001 & -0.003 & -0.028 & 0.026 & 0.017 & -0.289 & 0.045 & 41 & $\begin{array}{c}0.22 * \\
(0.0871)\end{array}$ \\
\hline & & & Prey & 0.101 & 0.120 & 0.005 & 0.151 & 0.055 & 1.031 & -0.650 & 41 & $\begin{array}{c}-1.11 \\
(0.3643)\end{array}$ \\
\hline & \multirow{2}{*}{$\begin{array}{l}\text { S\&P600 } \\
\text { small-cap }\end{array}$} & \multirow{2}{*}{$(0 ;-10)$} & Predator & 0.078 & 0.002 & -0.029 & 0.860 & 0.260 & 9.235 & 2.799 & 41 & $\begin{array}{c}0.94 \\
(0.3264)\end{array}$ \\
\hline & & & Prey & 0.169 & 0.122 & 0.007 & 0.887 & 0.247 & 7.138 & -0.575 & 41 & $\begin{array}{c}0.62 \\
(0.2324)\end{array}$ \\
\hline
\end{tabular}




\begin{tabular}{|c|c|c|c|c|c|c|c|c|c|c|c|c|}
\hline Measure & Market & Window & Firm & Mean & Median & Min & Max & Std Dev & Kurtosis & Skewness & $\mathbf{N}$. & z-test \\
\hline \multirow{4}{*}{ CARs } & \multirow{2}{*}{ S\&P500 } & \multirow{2}{*}{$(+1 ;-1)$} & Predator & 0.000 & 0.008 & -0.001 & 0.098 & 0.011 & 0.013 & 0.008 & 41 & $\begin{array}{c}0.19^{*} \\
(0.0715)\end{array}$ \\
\hline & & & Prey & 0.012 & 0.057 & 0.010 & 0.062 & 0.050 & 1.011 & -0.598 & 41 & $\begin{array}{c}-2.10 * * \\
(0.0179)\end{array}$ \\
\hline & \multirow{2}{*}{$\begin{array}{c}\text { S\&P600 } \\
\text { small-cap }\end{array}$} & \multirow{2}{*}{$(+1 ;-1)$} & Predator & 0.061 & 0.001 & 0.023 & 0.072 & 0.010 & 6.123 & 1.987 & 41 & $\begin{array}{c}0.25^{*} \\
(0.0987)\end{array}$ \\
\hline & & & Prey & 0.0113 & 0.092 & 0.010 & 0.023 & 0.002 & 5.028 & -0.348 & 41 & $\begin{array}{c}0.20^{*} \\
(0.0793)\end{array}$ \\
\hline
\end{tabular}

Note: The formula for CAPM is $E(R)=R_{f}+\beta_{i}\left(R_{m}-R_{f}\right)$ and cumulative abnormal return (CAR) is the sum of all abnormal returns, where the abnormal return is the difference of actual and expected returns. N.: is sample size and for each window, $(+)$ indicates number of days before the event happens and $(-)$ days after the event happened. 
Table 6: Alpha

\begin{tabular}{|c|c|c|c|c|c|c|c|c|c|c|c|c|}
\hline Measure & Market & Window & Firm & Mean & Median & Min & $\operatorname{Max}$ & Std Dev & Kurtosis & Skewness & N. & Z-test \\
\hline \multirow{8}{*}{ Sharpe } & \multirow{4}{*}{ S\&P 500} & \multirow{2}{*}{$(+150 ; 0)$} & Predator & 0.003 & 0.035 & -0.292 & 0.248 & 0.087 & 2.787 & -0.242 & 41 & $\begin{array}{c}-1.17 \\
(0.4564)\end{array}$ \\
\hline & & & Prey & 0.042 & 0.017 & -0.321 & 0.569 & 0.011 & 0.105 & 0.012 & 41 & $\begin{array}{c}7.23 \\
(0.9998)\end{array}$ \\
\hline & & \multirow{2}{*}{$(0 ;-32)$} & Predator & 0.000 & -0.012 & -0.196 & 0.181 & 0.082 & 1.210 & -0.045 & 41 & $\begin{array}{c}0.44 \\
(0.1700)\end{array}$ \\
\hline & & & Prey & 0.139 & 0.004 & -0.013 & 0.047 & 0.111 & 0.097 & 0.016 & 41 & $\begin{array}{c}3.92 \\
(0.9500)\end{array}$ \\
\hline & \multirow{4}{*}{$\begin{array}{l}\text { S\&P } 600 \\
\text { small-cap }\end{array}$} & \multirow{2}{*}{$(+150 ; 0)$} & Predator & -2.060 & -2.035 & -0.047 & 0.021 & 0.077 & 3.363 & -0.205 & 41 & $\begin{array}{c}-1.02 \\
(0.3461)\end{array}$ \\
\hline & & & Prey & 0.043 & 0.019 & -0.032 & 0.056 & 0.011 & 1.018 & 0.012 & 41 & $\begin{array}{c}7.13 \\
(0.9996)\end{array}$ \\
\hline & & \multirow{2}{*}{$(0 ;-32)$} & Predator & -2.030 & -2.044 & -0.382 & -0.043 & 0.072 & 1.433 & -0.041 & 41 & $\begin{array}{c}0.64 \\
(0.2389)\end{array}$ \\
\hline & & & Prey & 0.122 & 0.093 & -0.012 & 0.047 & 0.011 & 9.712 & 1.638 & 41 & $\begin{array}{c}8.43 \\
(0.9999) \\
\end{array}$ \\
\hline \multirow{8}{*}{ Treynor } & \multirow{4}{*}{ S\&P 500} & \multirow{2}{*}{$(+150 ; 0)$} & Predator & -0.047 & -0.104 & -0.144 & 0.074 & 0.035 & 0.512 & -0.018 & 41 & $\begin{array}{c}5.23 \\
(0.9912)\end{array}$ \\
\hline & & & Prey & 0.000 & 0.000 & -0.005 & 0.056 & 0.005 & 0.000 & 0.000 & 41 & $\begin{array}{c}0.21 * \\
(0.0832)\end{array}$ \\
\hline & & \multirow{2}{*}{$(0 ;-32)$} & Predator & -1.502 & -1.297 & -1.541 & 0.223 & 0.108 & 6.106 & -0.340 & 41 & $\begin{array}{c}-6.06 \\
(0.9976)\end{array}$ \\
\hline & & & Prey & 0.005 & -0.001 & -0.057 & 0.213 & 0.046 & 0.011 & 0.000 & 41 & $\begin{array}{c}0.41 \\
(0.1591)\end{array}$ \\
\hline & \multirow{4}{*}{$\begin{array}{l}\text { S\&P } 600 \\
\text { small-cap }\end{array}$} & \multirow{2}{*}{$(+150 ; 0)$} & Predator & -0.146 & 0.114 & -0.100 & 0.068 & 0.109 & 0.065 & 0.018 & 41 & $\begin{array}{c}-7.63 \\
(0.9997)\end{array}$ \\
\hline & & & Prey & 0.001 & 0.000 & -0.038 & 0.041 & 0.059 & 0.066 & 0.008 & 41 & $\begin{array}{c}0.03 * * \\
(0.0120)\end{array}$ \\
\hline & & \multirow{2}{*}{$(0 ;-32)$} & Predator & -0.107 & -0.121 & -0.045 & 0.185 & 0.091 & 0.073 & -0.008 & 41 & $\begin{array}{c}0.49 \\
(0.1879)\end{array}$ \\
\hline & & & Prey & -0.085 & -0.060 & -2.356 & 1.711 & 0.681 & 10.342 & -0.715 & 41 & $\begin{array}{l}-0.12^{* *} \\
(0.0478)\end{array}$ \\
\hline
\end{tabular}




\begin{tabular}{|c|c|c|c|c|c|c|c|c|c|c|c|c|}
\hline Measure & Market & Window & Firm & Mean & Median & Min & Max & Std Dev & Kurtosis & Skewness & N. & Z-test \\
\hline \multirow{8}{*}{ Jensen } & \multirow{4}{*}{ S\&P 500} & \multirow{2}{*}{$(+150 ; 0)$} & Predator & -0.030 & -0.030 & -0.072 & 0.007 & 0.012 & 3.456 & -0.168 & 41 & $\begin{array}{c}0.04 * * \\
(0.0160)\end{array}$ \\
\hline & & & Prey & -0.038 & -0.040 & -0.114 & 0.227 & 0.036 & 13.856 & 1.541 & 41 & $\begin{array}{c}0.26 \\
(0.1026)\end{array}$ \\
\hline & & \multirow{2}{*}{$(0 ;-32)$} & Predator & -0.032 & -0.032 & -0.063 & -0.007 & 0.012 & 1.392 & -0.075 & 41 & $\begin{array}{c}0.08^{* *} \\
(0.0319)\end{array}$ \\
\hline & & & Prey & -0.040 & -0.042 & -0.058 & 0.044 & 0.018 & 14.082 & 1.858 & 41 & $\begin{array}{c}0.48 \\
(0.1844)\end{array}$ \\
\hline & \multirow{4}{*}{$\begin{array}{l}\text { S\&P } 600 \\
\text { small-cap }\end{array}$} & \multirow{2}{*}{$(+150 ; 0)$} & Predator & -0.034 & -0.034 & -0.083 & 0.013 & 0.016 & 2.776 & -0.097 & 41 & $\begin{array}{l}0.01 * * * \\
(0.0040)\end{array}$ \\
\hline & & & Prey & -0.037 & -0.040 & -0.114 & 0.228 & 0.036 & 13.303 & 1.480 & 41 & $\begin{array}{c}0.27 \\
(0.1064)\end{array}$ \\
\hline & & \multirow{2}{*}{$(0 ;-32)$} & Predator & -0.035 & -0.035 & -0.070 & -0.004 & 0.014 & 1.054 & -0.029 & 41 & $\begin{array}{c}0.06 * * \\
(0.0239)\end{array}$ \\
\hline & & & Prey & -0.039 & -0.042 & -0.057 & 0.047 & 0.018 & 13.501 & 1.816 & 41 & $\begin{array}{c}0.49 \\
(0.1879) \\
\end{array}$ \\
\hline \multirow{8}{*}{$\begin{array}{l}\text { SIM-ERs } \\
\text { on the } \\
\text { stock }\end{array}$} & \multirow{4}{*}{ S\&P 500} & \multirow{2}{*}{$(+150 ; 0)$} & Predator & -0.040 & -0.040 & -0.086 & 0.001 & 0.012 & 6.283 & -0.219 & 41 & $\begin{array}{l}0.02 * * * \\
(0.0080)\end{array}$ \\
\hline & & & Prey & -0.038 & -0.041 & -0.114 & 0.227 & 0.036 & 13.879 & 1.540 & 41 & $\begin{array}{c}0.27 \\
(0.1064)\end{array}$ \\
\hline & & \multirow{2}{*}{$(0 ;-32)$} & Predator & -0.042 & -0.042 & -0.076 & -0.013 & 0.013 & 1.399 & -0.018 & 41 & $\begin{array}{c}0.04^{* *} \\
(0.0160)\end{array}$ \\
\hline & & & Prey & -0.039 & -0.042 & -0.057 & 0.046 & 0.018 & 14.178 & 1.862 & 41 & $\begin{array}{c}0.51 \\
(0.1950)\end{array}$ \\
\hline & \multirow{4}{*}{$\begin{array}{l}\text { S\&P } 600 \\
\text { small-cap }\end{array}$} & \multirow{2}{*}{$(+150 ; 0)$} & Predator & -0.040 & -0.040 & -0.086 & 0.001 & 0.012 & 6.283 & -0.219 & 41 & $\begin{array}{l}0.02 * * * \\
(0.0080)\end{array}$ \\
\hline & & & Prey & -0.038 & -0.041 & -0.114 & 0.227 & 0.036 & 13.879 & 1.540 & 41 & $\begin{array}{c}0.27 \\
(0.1064)\end{array}$ \\
\hline & & \multirow{2}{*}{$(0 ;-32)$} & Predator & -0.042 & -0.042 & -0.076 & -0.013 & 0.013 & 1.399 & -0.018 & 41 & $\begin{array}{c}0.04^{*} \\
(0.060)\end{array}$ \\
\hline & & & Prey & -0.039 & -0.042 & -0.057 & 0.046 & 0.018 & 14.178 & 1.862 & 41 & $\begin{array}{c}0.51 \\
(0.1950) \\
\end{array}$ \\
\hline
\end{tabular}




\begin{tabular}{|c|c|c|c|c|c|c|c|c|c|c|c|c|}
\hline Measure & Market & Window & Firm & Mean & Median & Min & Max & Std Dev & Kurtosis & Skewness & N. & Z-test \\
\hline \multirow{8}{*}{$\begin{array}{l}\text { SIM-ERs } \\
\text { on the } \\
\text { market }\end{array}$} & \multirow{4}{*}{ S\&P 500} & \multirow{2}{*}{$(+150 ; 0)$} & Predator & -0.030 & -0.030 & -0.072 & 0.007 & 0.012 & 3.468 & -0.169 & 41 & $\begin{array}{c}0.05^{* *} \\
(0.0199)\end{array}$ \\
\hline & & & Prey & -0.038 & -0.041 & -0.114 & 0.227 & 0.036 & 13.879 & 1.540 & 41 & $\begin{array}{c}0.27 \\
(0.1064)\end{array}$ \\
\hline & & \multirow{2}{*}{$(0 ;-32)$} & Predator & -0.032 & -0.032 & -0.063 & -0.007 & 0.012 & 1.406 & -0.067 & 41 & $\begin{array}{c}0.09 * * \\
(0.0359)\end{array}$ \\
\hline & & & Prey & -0.039 & -0.042 & -0.057 & 0.046 & 0.018 & 14.178 & 1.862 & 41 & $\begin{array}{c}-0.20^{*} \\
(0.0793)\end{array}$ \\
\hline & \multirow{4}{*}{$\begin{array}{l}\text { S\&P } 600 \\
\text { small-cap }\end{array}$} & \multirow{2}{*}{$(+150 ; 0)$} & Predator & -0.034 & -0.034 & -0.078 & 0.006 & 0.013 & 3.671 & -0.159 & 41 & $\begin{array}{l}-0.02^{* * *} \\
(0.0080)\end{array}$ \\
\hline & & & Prey & -0.038 & -0.041 & -0.114 & 0.227 & 0.036 & 13.879 & 1.540 & 41 & $\begin{array}{c}0.27 \\
(0.1064)\end{array}$ \\
\hline & & \multirow{2}{*}{$(0 ;-32)$} & Predator & -0.035 & -0.035 & -0.068 & -0.006 & 0.013 & 1.476 & -0.051 & 41 & $\begin{array}{c}0.05^{* *} \\
(0.0199)\end{array}$ \\
\hline & & & Prey & -0.039 & -0.042 & -0.057 & 0.046 & 0.018 & 14.178 & 1.862 & 41 & $\begin{array}{c}0.51 \\
(0.1950) \\
\end{array}$ \\
\hline
\end{tabular}

Note: The Jensen formula; $\alpha_{j}=R_{i}-\left[R_{f}+B_{i}\left(R_{m}-R_{f}\right)\right]$, Sharpe; $S=\frac{\left(R_{a}-R_{b}\right)}{\sigma}$, Treynor; $T=\frac{\left(R_{i}-R_{f}\right)}{\beta_{i}}$ and SIM; $R_{i t}-R_{f}=\alpha_{i}+\beta_{i}\left(R m t-R_{f}\right)+$ $\varepsilon_{i t} . E(R)$ is the expected return, $R_{f}$ is the risk-free interest rate, $\beta_{i}$ is the portfolio beta, $R_{m}$ is market return, $R_{i}$ is the portfolio return, $R_{a}$ is the asset return, $R_{b}$ is the bench marking returns such as $R_{f}$ or index returns and $\sigma$ is the standard deviation, $r_{i t}$ is return to stock $i$ in period $t, r_{f}$ is the riskfree interest rate, $r_{m t}$ is the return to the market portfolio in period $t, \alpha_{i}$ is the stock's alpha, or abnormal return, $R_{i t}-R_{f}$ is the ER on the stock, $R_{i t}-R_{m t}$ is the ER on the market, $\beta_{i}$ is the stock's beta (or responsiveness to the market return) and $\varepsilon_{i t}$ is the residual (random) return, which is assumed normally distributed with mean zero and standard deviation $\sigma_{i}$. N.: is sample size and for each window, $(+)$ indicates number of days before the event happens and $(-)$ days after the event happened. 